\title{
The Eurasian Modern Pollen Database (EMPD), version 2
}

Basil A. S. Davis ${ }^{1}$, Manuel Chevalier ${ }^{1}$, Philipp Sommer ${ }^{1}$, Vachel A. Carter ${ }^{2}$, Walter Finsinger ${ }^{3}$, Achille Mauri ${ }^{4}$, Leanne N. Phelps ${ }^{1}$, Marco Zanon ${ }^{5}$, Roman Abegglen ${ }^{6}$, Christine M. Åkesson ${ }^{7}$, Francisca Alba-Sánchez ${ }^{8}$, R. Scott Anderson ${ }^{9}$, Tatiana G. Antipina ${ }^{10}$, Juliana R. Atanassova ${ }^{11}$, Ruth Beer $^{6}$, Nina I. Belyanina ${ }^{12}$, Tatiana A. Blyakharchuk ${ }^{13}$, Olga K. Borisova ${ }^{14}$, Elissaveta Bozilova ${ }^{15}$, Galina Bukreeva $^{16}$, M. Jane Bunting ${ }^{17}$, Eleonora Clò ${ }^{18}$, Daniele Colombaroli ${ }^{19}$, Nathalie Combourieu-Nebout ${ }^{20}$, Stéphanie Desprat ${ }^{21}$, Federico Di Rita ${ }^{22}$, Morteza Djamali ${ }^{23}$, Kevin J. Edwards ${ }^{24}$, Patricia L. Fall ${ }^{25}$, Angelica Feurdean ${ }^{26}$, William Fletcher $^{27}$, Assunta Florenzano ${ }^{18}$, Giulia Furlanetto ${ }^{28}$, Emna Gaceur ${ }^{29}$, Arsenii T. Galimov ${ }^{10}$, Mariusz Gałka ${ }^{30}$, Iria García-Moreiras ${ }^{31}$, Thomas Giesecke $^{32}$, Roxana Grindean ${ }^{33}$, Maria A. Guido ${ }^{34}$, Irina G. Gvozdeva ${ }^{35}$, Ulrike Herzschuh ${ }^{36}$, Kari L. Hjelle $^{37}$, Sergey Ivanov ${ }^{38}$, Susanne Jahns ${ }^{39}$, Vlasta Jankovska ${ }^{40}$, Gonzalo Jiménez-Moreno ${ }^{41}$, Monika Karpińska-Kołaczek ${ }^{42}$, Ikuko Kitaba ${ }^{43}$, Piotr Kołaczek ${ }^{42}$, Elena G. Lapteva ${ }^{44}$, Małgorzata Latałowa ${ }^{45}$, Vincent Lebreton ${ }^{46}$, Suzanne Leroy ${ }^{47}$, Michelle Leydet ${ }^{48}$, Darya A. Lopatina ${ }^{49}$, José Antonio López-Sáez ${ }^{50}$, André F. Lotter ${ }^{6}$, Donatella Magri' ${ }^{22}$, Elena Marinova ${ }^{51}$, Isabelle Matthias ${ }^{52}$, Anastasia Mavridou ${ }^{53}$, Anna Maria Mercuri ${ }^{18}$, Jose Manuel Mesa-Fernández ${ }^{41}$, Yuri A. Mikishin ${ }^{35}$, Krystyna Milecka $^{42}$, Carlo Montanari ${ }^{54}$, César Morales-Molino ${ }^{6}$, Almut Mrotzek ${ }^{55}$,

Castor Muñoz Sobrino ${ }^{31}$, Olga D. Naidina ${ }^{56}$, Takeshi Nakagawa ${ }^{43}$, Anne Birgitte Nielsen ${ }^{57}$, Elena Y. Novenko ${ }^{58}$, Sampson Panajiotidis ${ }^{53}$, Nata K. Panova ${ }^{10}$, Maria Papadopoulou ${ }^{53}$,

Heather S. Pardoe ${ }^{59}$, Anna Pędziszewska ${ }^{45}$, Tatiana I. Petrenko ${ }^{35}$, María J. Ramos-Román ${ }^{60}$, Cesare Ravazzi $^{28}$, Manfred Rösch ${ }^{61}$, Natalia Ryabogina ${ }^{38}$, Silvia Sabariego Ruiz ${ }^{62}$, J. Sakari Salonen ${ }^{60}$, Tatyana V. Sapelko ${ }^{63}$, James E. Schofield ${ }^{24}$, Heikki Seppä ${ }^{60}$, Lyudmila Shumilovskikh ${ }^{64}$, Normunds Stivrins $^{65}$, Philipp Stojakowits ${ }^{66}$, Helena Svobodova Svitavska ${ }^{67}$,

Joanna Święta-Musznicka ${ }^{45}$, Ioan Tantau ${ }^{33}$, Willy Tinner ${ }^{6}$, Kazimierz Tobolski ${ }^{42, \boldsymbol{\dagger}}$, Spassimir Tonkov ${ }^{15}$, Margarita Tsakiridou $^{53}$, Verushka Valsecchi ${ }^{6}$, Oksana G. Zanina ${ }^{68}$, and Marcelina Zimny ${ }^{45}$

${ }^{1}$ Institute of Earth Surface Dynamics IDYST, Faculté des Géosciences et l'Environnement, University of Lausanne, Batiment Géopolis, 1015, Lausanne, Switzerland

${ }^{2}$ Department of Botany, Charles University, Benatska 2, Prague 2 128-01, Czech Republic

${ }^{3}$ ISEM, CNRS, University of Montpellier, EPHE, IRD, Montpellier, France

${ }^{4}$ European Commission Joint Research Centre, Directorate D - Sustainable Resources - Bio-Economy Unit, Via E. Fermi 2749, 21027 Ispra (VA), Italy

${ }^{5}$ Institute of Pre- and Protohistoric Archaeology, Kiel University, Johanna-Mestorf-Str. 2-6, 24118 Kiel, Germany

${ }^{6}$ Institute of Plant Sciences, University of Bern, Altenbergrain 21, Bern, Switzerland

${ }^{7}$ Department of Geography and Sustainable Development, University of St Andrews, North Street, St Andrews, KY16 9AL, UK

${ }^{8}$ Department of Botany, University of Granada, Avda. Fuente Nueva, 18071-Granada, Spain

${ }^{9}$ School of Earth and Sustainability, 624 S. Knoles St., Ashust Building, Room A108, Flagstaff, AZ, USA

${ }^{10}$ Botanical Garden of the Ural Branch of the Russian Academy of Sciences, 620144, Yekaterinburg, Russia

${ }^{11}$ Biological Faculty, Department of Botany, Sofia University, 8 Dragan Tzankov bld., 1164 Sofia, Bulgaria

${ }^{12}$ Pacific Institute of Geography FEB RAS, 7, Radio Street, 690042, Vladivostok, Russia

${ }^{13}$ Institute of Monitoring of Climatic and Ecological Systems of Siberian Branch of Russian Academy of

Sciences, Akademicheski ave. 10/3, 634055, Tomsk, Russia

${ }^{14}$ Russian Academy of Sciences, Institute of Geography, Staromonetny lane 29, 119017, Moscow, Russia

${ }^{15}$ Faculty of Biology, Laboratory of Palynology, Sofia University, 8 Dragan Tsankov blvd., 1164 Sofia, Bulgaria 
${ }^{16}$ Siberian Branch of the Russian Academy of Sciences, c/o N. Ryabogina, Tyumen Scientific Centre SB RAS, Malygina st. 86, 625026, Tyumen, Russia

${ }^{17}$ Department of Geography, Geology and Environment, University of Hull, Cottongham Road, Hull, HU67RX, UK

${ }^{18}$ Laboratorio di Palinologia e Paleobotanica - Dipartimento Scienze della Vita,

Università di Modena e Reggio Emilia, via Campi 287, 41125 Modena, Italy

${ }^{19}$ Department of Geography, Royal Holloway University of London, Egham, Surrey TW20 0EX, UK

${ }^{20}$ UMR 7194 - CNRS/MNHN, Dpt Homme et Environnement, Institut de Paléontologie Humaine 1, rue René Panhard, 75013 Paris, France

${ }^{21}$ University of Bordeaux, EPOC UMR 5805, EPHE- PSL University, Allée Geoffroy St Hilaire, 33615 Pessac, France

${ }^{22}$ Department of Environmental Biology, Sapienza University, Piazzale Aldo Moro, 5, Rome, Italy

${ }^{23}$ Institut Méditerranéen de Biodiversité et d'Ecologie, Aix-Marseille Université - Campus Aix Technopôle de l'environnement Arbois Méditerranée Avenue Louis Philibert Bât Villemin - BP 80, 13545 Aix-en-Provence CEDEX 4, France

${ }^{24}$ Departments of Geography and Environment and Archaeology, School of Geosciences, University of Aberdeen, Elphinstone Road, Aberdeen AB24 3UF, UK

${ }^{25}$ Department of Geography \& Earth Sciences, University of North Carolina, Charlotte, NC, USA

${ }^{26}$ Department of Physical Geography, Goethe University, Altenhöferallee 1, 60438 Frankfurt am Main, Germany

${ }^{27}$ Quaternary Environments and Geoarchaeology Group, Department of Geography, School of Environment, Education and Development, University of Manchester, Oxford Road, Manchester, M13 9PL, UK

${ }^{28}$ CNR-IGAG, Laboratory of Palynology and Palaeoecology, Piazza della Scienza 1, 20126 Milan, Italy

${ }^{29}$ GEOGLOB, Faculty of Sciences of Sfax, Route Soukra, BP. 802, 3038 Sfax, Tunisia

${ }^{30}$ Faculty of Biology and Environmental Protection, Department of Geobotany and Plant Ecology, University of Łódź, Banacha Str. 12/16, 90-237 Łódź, Poland

${ }^{31}$ Dpto. Bioloxía Vexetal e Ciencias do Solo, Facultade de Ciencias, Universidade de Vigo, 36310, Vigo, Spain

${ }^{32}$ Department of Physical Geography, Faculty Geoscience, Utrecht University, P.O. Box 80115, 3508 TC, Utrecht, the Netherlands

${ }^{33}$ Department of Geology, Babes-Bolyai University, Kogalniceanu Street, 400084, Cluj-Napoca, Romania

${ }^{34}$ CIR-LASA - University of Genoa, Via Balbi, 6, 16126, Genoa, Italy, Italy

${ }^{35}$ Far East Geological Institute FEB RAS, 159, Prospekt 100-letiya, 690022, Vladivostok, Russia

${ }^{36}$ Alfred Wegener Institute Helmholtz Centre for Polar and Marine Research, Telegraphenberg A45, Potsdam, Germany

${ }^{37}$ Department of Natural History, University Museum, University of Bergen, P.O. Box 7800, 5020 Bergen, Norway

${ }^{38}$ Tyumen Scientific Centre SB RAS, Malygina st. 86, 625026, Tyumen, Russia

${ }^{39}$ Brandenburgisches Landesamt für Denkmalpflege, Wünsdorfer Platz 4-5, 15806 Zossen OT Wünsdorf, Germany

${ }^{40}$ Paleoecological Laboratory, Institute of Botany, Academy of the Sciences of the Czech Republic, Lidická 25/27, 60200 BRNO, Czech Republic

${ }^{41}$ Departamento de Estratigrafía y Paleontología, Universidad de Granada, Avda. Fuentenueva S/N, 18002 Granada, Spain

${ }^{42}$ Laboratory of Wetland Ecology and Monitoring, Adam Mickiewicz University, B. Krygowskiego 10/247, 61-680 Poznań, Poland

${ }^{43}$ Research Centre for Palaeoclimatology, Ritsumeikan University, 1-1-1 Noji-Higashi, Kusatsu, Shiga 525-8577, Japan

${ }^{44}$ Laboratory of Paleoecology, Institute of Plant and Animal Ecology of the Ural Branch of the Russian Academy of Sciences, 8 Matra str., 202, 620144, Yekaterinburg, Russia

${ }^{45}$ Department of Plant Ecology, Laboratory of Palaeoecology \& Archaeobotanyul, University of Gdańsk, Wita Stwosza 59, 80-308 Gdańsk, Poland

${ }^{46}$ CNRS/Muséum National d'Histoire Naturelle, UMR 7194 - Institut de Paléontologie Humaine 1, rue René Panhard, 75013 Paris, France

${ }^{47}$ AMU-LAMPEA, Aix Marseille Univ, CNRS, Minist Culture, LAMPEA, UMR 7269, 5 rue du Château de l'Horloge, 13094, Aix-en-Provence, France 
${ }^{48}$ Aix Marseille Univ, Avignon Université, CNRS, IRD, IMBE, Europôle Arbois, Aix-en-Provence, France

${ }^{49}$ Laboratory of Stratigraphy and Paleogeography of oceans Geological Institute Russian Academy of Sciences, Pyzevskii per., 119017, Moscow, Russia

${ }^{50}$ Instituto de Historia-CSIC, Albasanz 26-28, 28037 Madrid, Spain

${ }^{51}$ State Office for Cultural Heritage Baden Württemberg, Laboratory for Archaeobotany, Fischersteig 9, 78343 Hemmenhofen, Germany

${ }^{52}$ Campus Institute Data Science, Göttingen, Germany

${ }^{53}$ Laboratory of Forest Botany-Geobotany, Faculty of Forestry and Natural Environment, Aristotle University of Thessaloniki, Thessaloniki, Greece

${ }^{54}$ University of Genoa, DISTAV - Corso Europa, 26, Genoa, Italy

${ }^{55}$ Institute of Botany and Landscape Ecology, University of Greifswald, Soldmannstr. 15, 17487 Greifswald, Germany

${ }^{56}$ Geological Institute RAS, Pyzhevsky 7, 119017, Moscow, Russia

${ }^{57}$ Lund University, Sölvegatan 12, 66362 Lund, Sweden

${ }^{58}$ Faculty of geography, Department of Physical Geography and Landscape Science, Lomonosov Moscow State University, Leninskiye gory, 1., 119991, Moscow, Russia

${ }^{59}$ National Museum Wales, Cathays Park, Cardiff CF10 3NP, UK

${ }^{60}$ Department of Geosciences and Geography, University of Helsinki, P.O. Box 64 (Gustaf Hällströmin katu 2), F00014, Helsinki, Finland

${ }^{61}$ Department of Philosophy, Universität Heidelberg, Sandgasse 7, 69117 Heidelberg, Germany

${ }^{62}$ Dept. de Biodiversidad, Ecología y Evolución, Universidad Complutense de Madrid, Ciudad Universitaria 28040, Madrid, Spain

${ }^{63}$ Institute of Limnology, RAS, 9, Sevastyanova st., 196105, St. Petersburg, Russia

${ }^{64}$ Department of Palynology and Climate Dynamics, University of Göttingen, Wilhelm-Weber-Str. 2a, 37073 Göttingen, Germany

${ }^{65}$ Department of Geography, University of Latvia, Jelgavas str. 1, 1004, Riga, Latvia

${ }^{66}$ Institute of Geography, University of Augsburg, Alter Postweg 118, 86159 Augsburg, Germany

${ }^{67}$ Institute of Botany, Czech Academy of Sciences, Zámek 1, 25243 Pruhonice, Czech Republic

${ }^{68}$ RAS, Laboratory of Soil Cryology, Institute of Physico-Chemical and Biological Problems in Soil Science, Moscow region, Institutskaya 2, 142290, Pushchino, Russia

$\boldsymbol{t}_{\text {deceased }}$

Correspondence: Basil A. S. Davis (basil.davis@unil.ch)

Received: 21 January 2020 - Discussion started: 24 February 2020

Revised: 15 May 2020 - Accepted: 7 August 2020 - Published: 9 October 2020

Abstract. The Eurasian (née European) Modern Pollen Database (EMPD) was established in 2013 to provide a public database of high-quality modern pollen surface samples to help support studies of past climate, land cover, and land use using fossil pollen. The EMPD is part of, and complementary to, the European Pollen Database (EPD) which contains data on fossil pollen found in Late Quaternary sedimentary archives throughout the Eurasian region. The EPD is in turn part of the rapidly growing Neotoma database, which is now the primary home for global palaeoecological data. This paper describes version 2 of the EMPD in which the number of samples held in the database has been increased by $60 \%$ from 4826 to 8134 . Much of the improvement in data coverage has come from northern Asia, and the database has consequently been renamed the Eurasian Modern Pollen Database to reflect this geographical enlargement. The EMPD can be viewed online using a dedicated map-based viewer at https://empd2.github.io and downloaded in a variety of file formats at https: //doi.pangaea.de/10.1594/PANGAEA.909130 (Chevalier et al., 2019). 


\section{Introduction}

Modern pollen samples provide an essential source of information for interpreting and understanding the fossil pollen record, which in turn provides one of the most important spatially resolved sources of information on Quaternary vegetation and climate. We use the term "fossil pollen" here as it is commonly used in the Quaternary sciences. The fossils in this sense can more accurately be described as sub-fossils since they have usually only undergone limited (if any) postdeposition mineralisation, while pollen is taken to include many spores as well as the pollen from flowering plants. Fossil pollen can be found preserved in sediments in lakes and bogs and other anaerobic environments throughout the Eurasian region extending back throughout the Quaternary. Modern pollen is simply the component of that fossil record found in the last 100-150 years, most often in the surface layers of lake and bog sediments, but also including comparable collectors of pollen such as moss polsters.

Davis et al. (2013) include a comprehensive introduction to the different scientific uses of modern pollen samples. Modern pollen samples have been used to interpret many different environmental processes, such as past changes in land cover, land use, and human impact; the impact on vegetation of past edaphic and hydroseral changes; and the effects of past changes in fire, pests, and disease on vegetation. Modern samples have also been used to understand taphonomic problems with regard to pollen transport, deposition, and preservation. One of the early motivations for establishing large modern pollen datasets and one that still remains important is their use as calibration "training sets" for the quantitative reconstruction of past climate. This approach has also more recently been adapted to quantitative reconstructions of land cover, where a similar modelling approach to climate reconstruction is applied to determine, for instance, forest cover. Similarly, modern samples have also been used to establish and model the relationship between vegetation and pollen assemblages based on the different pollen productivity of different taxa and thereby provide quantitative estimates of past vegetation composition in a landscape from records of fossil pollen.

Historically, modern pollen data were often gathered directly for a particular research project, but the data were rarely shared and if published often in grey literature such as a thesis, report, or monograph. Efforts to develop larger datasets at continental scales were pioneered in the 1990s, primarily by research groups looking to use these datasets as calibration datasets for quantitative climate reconstruction. Development however was haphazard, and the datasets had a reputation for being poorly documented and quality controlled, often containing duplicates, digitised data (not original raw counts), uncertain taxonomic standardisation, poor geolocation information, and loose definitions of "modern" that could embrace as much as the last 500 years. It became increasingly clear that a quality controlled and stan- dardised database of modern pollen samples was required, comparable to the European Pollen Database (EPD) for fossil pollen samples and reflecting the same open-access and community-based principles.

The Eurasian (née European) Modern Pollen Database (EMPD) was therefore established in 2013 as a complement to the European Pollen Database (EPD) for fossil pollen (Davis et al., 2013). The first version of the EMPD (referenced herein as the EMPD1) contained almost 5000 samples, submitted by over 40 individuals and research groups from all over Europe. Over the last 6 years more data have continued to be submitted, and additional efforts have been made to incorporate more data held in open data repositories such as PANGAEA and made available as a supplement in published studies. This paper documents the first update to the EMPD (referenced herein as EMPD2), in which the number of samples stored in the database has increased by around $60 \%$.

The EMPD remains the only open-access database of modern pollen samples covering the Eurasian continent. Smaller compilations of modern pollen samples exist for some regions, but these generally have limitations in terms of some or all of the following: (1) the extent of metadata provided, (2) the completeness of the taxa assemblage, (3) the standardisation of taxa nomenclature and hierarchy with respect to the EPD, (4) the inclusion of digitised rather than original raw count data, (5) the inclusion of percentages rather than raw counts, (6) information about the original source of the data and the analyst, and in some cases, (7) limitations to public access. Importantly, all of these aspects limit their compatibility with the EPD, where compatibility with the EPD is one of the primary objectives of the EMPD. The EMPD contains only the original raw count data (no percentage data) for the complete pollen assemblage. The EMPD also contains comprehensive and standardised metadata about the pollen sample location, the landscape and vegetation environment from which it was collected, the way it was collected, the year that it was collected, and who collected and analysed the sample and where it was published.

The EMPD has no formal spatial domain, but in general it covers the same geographic region as the EPD. This has traditionally been the Palearctic vegetation region of Eurasia excluding China, which has established its own semi-private regional database. As well as the terrestrial Eurasian landmass and associated islands, it also includes marine samples from coastal margins and enclosed seas. Increasingly however these geographical administrative boundaries have become blurred as regional pollen databases become integrated into the global Neotoma Palaeoecology Database (Williams et al., 2018), hereafter referred to as "Neotoma". While regional databases such as the EPD will outwardly retain their identity within Neotoma, internally the data will be completely integrated at a global level. It is also planned that the EMPD will become integrated into Neotoma in the near future, and with this in mind, the EMPD2 also includes data 
Table 1. List of metadata fields used in the EMPD.

\begin{tabular}{lll}
\hline Sample name & Original authors' sample name & Free text \\
Sigle & EMPD unique sample identifier & Assigned \\
Site name & Original authors' site name & Free text \\
Country & Country where the site is located & List \\
Longitude & Longitude in decimal degrees & Numeric \\
Latitude & Latitude in decimal degrees & Numeric \\
Elevation & Elevation in metres above sea level & Numeric \\
Location & Reliability estimate of the accuracy of the geolocation information & List \\
Location notes & Notes about the site location & Free text \\
Area of site & Site size in hectares & Numeric \\
Sample context & Physical environment of the site & List \\
Site description & Notes about the physical context of the site & Free text \\
Vegetation & Description notes about the surrounding vegetation & Free text \\
Sample type & The type of material or sediment sampled & List \\
Sample method & The method used to obtain the pollen sample & List \\
Age BP & The age of the sample BP & Numeric \\
Age uncertainty & The age uncertainty associated with the sample & List \\
Notes & General notes concerning the sample and site & Free text \\
Publications $1-4$ & Any publications associated with the sample & Free text \\
Worker role & The name of the responsible person or analyst & Free text \\
Worker details & Address and contact details for this person & Free text \\
\hline
\end{tabular}

from outside of the traditional EPD region on the basis that it represented the most expeditious route to making these data publicly available within Neotoma. Consequently, this second version of the EMPD includes not only data from Europe and northern Asia, but also data from Greenland, India, China, and North Africa.

\section{Methods}

Details about the structure and metadata of the database have already been described in detail by Davis et al. (2013). The list of metadata fields is shown in Table 1. We also include climate and vegetation data for each sample location. The climate data include mean monthly, seasonal, and annual temperature and precipitation climatology from WorldClim2 (Fick and Hijmans, 2017). The climate was assigned according to the nearest grid point within the $30 \mathrm{~s}$ (approximately $1 \mathrm{~km}^{2}$ ) resolution of the WorldClim 2 grid. The vegetation data include realm, biome, and ecoregion, taken from Olson et al. (2001). Note that all samples have been assigned a biome, including marine samples. The biome assigned to marine samples was based on the nearest point of land to the sample. No climate has been assigned to marine samples.

The protocol for the database follows that of the European Pollen Database, with some additions. The EMPD only includes samples younger than $200 \mathrm{BP}$, and with a sampling resolution comparable with the fossil pollen in the EPD. For instance, the EMPD does not include pollen trap data gathered at monthly or annual resolution, but it does accept trap data averaged over a period of at least 10 years, which is more comparable with the time typically represented in a fossil pollen sample taken from a sediment core.

Like the EPD, the EMPD only includes raw count data representing the full pollen assemblage, and it does not contain percentage data or truncated or summary assemblages. Percentages are excluded because their calculation can vary from author to author, and therefore unlike raw count data it is not always possible to directly compare different samples from different sources with percentage data. This is an important data quality criteria, but it has led to the exclusion of some large regional modern pollen datasets that have been recently published. This is discussed in the next section.

Modern pollen samples have been gathered from a variety of depositional environments, and the type of environment is recorded for $75 \%$ of the samples in the database. The most common environments are moss polsters $(31 \%)$, soil $(21 \%)$, and lake sediments (19\%).

\subsection{Data sources}

The pollen data for the latest update of the EMPD have come from a diverse range of sources, but mainly submissions from individual researchers and research groups. Most of this has been the result of published research (Table 2), but we also include unpublished data. Additional pollen data have come from open-access sources such as the PANGAEA data archive and data supplements to publications, as well as new fossil pollen data submitted to the EPD and Neotoma since EMPD1 where the sample age of a sediment core top fulfils the requirements of a modern pollen sample. 
Table 2. List of data submitted to the EMPD2 by country.

\begin{tabular}{|c|c|c|c|}
\hline Sample(s) & Country & Contributor(s) & Publication(s) \\
\hline 3 & Belarus & Binney, H. & Binney et al. $(2016,2017)$ \\
\hline 41 & Bulgaria & $\begin{array}{l}\text { Atanassova, J., Lazarova, M., Tonkov, } \\
\text { S. }\end{array}$ & Atanassova (2007); Lazarova et al. (2006) \\
\hline 33 & $\begin{array}{l}\text { China, People's } \\
\text { Republic of }\end{array}$ & Binney, H. & Binney et al. $(2016,2017)$ \\
\hline 56 & Cyprus & Fall, P. & Fall (2012) \\
\hline 47 & Czech Republic & Svobodova Svitavska, H. & $\begin{array}{l}\text { Helena (2004); Pardoe et al. (2010); Svobodová (1989, } \\
\text { 1997, 2002); Svobodová et al. (2001) }\end{array}$ \\
\hline 1 & Finland & Stivrins, N. & Stivrins et al. (2017b) \\
\hline 4 & France & Leroy, S. & \\
\hline 4 & Georgia & Binney, $\mathrm{H}$. & Binney et al. $(2016,2017)$ \\
\hline 85 & Germany & $\begin{array}{l}\text { Giesecke, T., Matthias, I., Mrotzek, A., } \\
\text { Rösch, M., Stojakowits, P. }\end{array}$ & $\begin{array}{l}\text { Lechterbeck (2001); Matthias et al. (2012, 2015); } \\
\text { Mrotzek et al. (2017); Rösch et al. (2017); Rösch (2009, } \\
\text { 2012, 2013, 2018); Rösch and Lechterbeck (2016); } \\
\text { Rösch and Tserendorj (2011a, b); Rösch and Wick } \\
\text { (2019); Stojakowits (2015) }\end{array}$ \\
\hline
\end{tabular}

\begin{tabular}{|c|c|c|c|}
\hline 76 & Greece & $\begin{array}{l}\text { Jahns, S., López Sáez, J., Mavridou, } \\
\text { A., Panajiotidis, S., Papadopoulou, M., } \\
\text { Tsakiridou, M. }\end{array}$ & Glais et al. (2016); Jahns (1992); Pardoe et al. (2010) \\
\hline 64 & Greenland & Edwards, K., Schofield, J. & Schofield et al. (2007) \\
\hline 4 & Iceland & Hallsdottir, M., Stivrins, N. & \\
\hline 16 & India & Demske, D., Tarasov, P. & Leipe et al. (2014) \\
\hline 64 & $\begin{array}{l}\text { Iran, Islamic } \\
\text { Republic of }\end{array}$ & Djamali, M., Leroy, S., Ramezani, E. & $\begin{array}{l}\text { Djamali et al. (2009); Haghani et al. (2016); Leroy et al. } \\
(2011,2018) \text {; Ramezani et al. (2013) }\end{array}$ \\
\hline 243 & Italy & $\begin{array}{l}\text { Accorsi, C., Badino, F., Champvillair, } \\
\text { E., Clò, E., Colombaroli, D., Di Rita, F., } \\
\text { Finsinger, W., Florenzano, A., Furlan- } \\
\text { etto, G., Greggio, B., Joannin, S., Leroy, } \\
\text { S., Lotter, A., Magri, D., Mercuri, A., } \\
\text { Montanari, C., Rattighieri, E., Ravazzi, } \\
\text { C., Suanno, C., Tinner, W., Valsecchi, } \\
\text { V. }\end{array}$ & $\begin{array}{l}\text { Abbate, 1981; Finsinger et al. (2007, 2010); Florenzano } \\
\text { et al. (2017); Florenzano and Mercuri (2018); Furlan- } \\
\text { etto et al. (2019); Guido et al., 1992; Joannin et al. } \\
\text { (2012); Margaritelli et al. (2016); Mercuri et al. (2012); } \\
\text { Montali et al. (2006); Montanari and Guido (1994); Rat- } \\
\text { tighieri et al. (2010) (2012); Di Rita et al. (2011, 2018a, } \\
\text { b); Di Rita and Magri (2009) }\end{array}$ \\
\hline 84 & Japan & $\begin{array}{l}\text { Kitaba, I., Leipe, C., Nakagawa, T., } \\
\text { Watanabe, M. }\end{array}$ & Leipe et al. (2018) \\
\hline 5 & Kazakhstan & $\begin{array}{l}\text { Duryagina, N., Naidina, O., } \\
\text { Nepomilueva, N. }\end{array}$ & $\begin{array}{l}\text { Naidina and Richards (2018); } \\
\text { Nepomilueva and Duryagin (1990) }\end{array}$ \\
\hline 43 & Kyrgyzstan & $\begin{array}{l}\text { Beer, R., Morales-Molino, C., Tinner, } \\
\text { W. }\end{array}$ & Beer et al. (2007) \\
\hline 10 & Latvia & Stivrins, N. & $\begin{array}{l}\text { Feurdean et al. (2017); Grudzinska et al. (2017); } \\
\text { Stivrins et al. (2014, 2015a, b, 2016b, a, 2017a); Veski } \\
\text { et al. (2012) }\end{array}$ \\
\hline 120 & Morocco & $\begin{array}{l}\text { Alba-Sánchez, F., Fletcher, W., } \\
\text { Sabariego Ruiz, S. }\end{array}$ & Bell and Fletcher (2016) \\
\hline
\end{tabular}


Table 2. Continued.

\begin{tabular}{llll}
\hline Sample(s) & Country & Contributor(s) & Publication(s) \\
\hline 231 & Norway & Hjelle, K., Pardoe, H. & $\begin{array}{l}\text { Caseldine and Pardoe (1994); Hjelle et al. (2015); } \\
\text { Hjelle and Sugita (2012); Mehl and Hjelle (2016); Par- } \\
\text { doe, (1992, 2001, 2006, 2014) }\end{array}$ \\
\hline 115 & Poland & $\begin{array}{l}\text { Gałka, M., Karpińska-Kołaczek, M., } \\
\text { Kołaczek, P., Latałowa, M., Milecka, }\end{array}$ & $\begin{array}{l}\text { Gałka et al. (2014, 2017); Milecka et al. (2017); Pardoe } \\
\text { et al. (2010); Pędziszewska (2008); Pędziszewska et al. } \\
(2015) ; \text { Pędziszewska and Latałowa (2016); Pidek et al. } \\
\end{array}$ \\
& & Kimny, M., Święta-Musznicka, J. & (2010) \\
\hline 12 & Portugal & Fletcher, W. & Fletcher (2005) \\
\hline 17 & Romania & Feurdean, A., Grindean, R., Tantau, I. & $\begin{array}{l}\text { Fărcaş and Tanţău (2012); Feurdean et al. (2009, 2013, } \\
\text { 2015); Feurdean and Willis (2008a, b); Grindean et al. } \\
\text { (2014, 2015); Tanţău et al. (2014a, b, 2009, 2011) }\end{array}$ \\
\hline
\end{tabular}

\begin{tabular}{ll}
\hline 1883 & Russian \\
& Federation
\end{tabular}

Antipina, T., Aseev, N., Belyanina, N., Binney, H., Blyakharchuk, T., Borisova, O., Bukreeva, G., Duryagin, D., Duryagina, N., Dyuzhova (Krasnorutskaya), K., Erokhin, N., Feurdean, A., Galimov, A., Golubeva, Y., Gvozdeva, I., Herzschuh, U., Ivanov, S., Karaulova, L., Khaymusova, N., Khizhnyak, N., Kremenetsky, N., Lapteva, E., Lopatina, D., Makovsky, N., Makovsky, V., Marchenko-Vagapova, T., Marieva, N., Matishov, G., Mikishin, Y., Müller, S., Naidina, O., Nepomilueva, N., Niemeyer, B., Nikiforova, L., Nosevich, E., Nosova, M., Novenko, E., Panova, N., Panova, N., Petrenko, T., Pisareva, V., Pisareva, N., Plotnikova, N., Ryabogina, N., Salonen, J., Sapelko, T., Semochkina, T., Seppä, H., Severova, E., Stivrins, N., Surova, N., Troitskiy, N., Vlasta Jankovska, N., Volkova, O., Yankovska, N., Zanina, O., Zelikson, E., Zhuykova, I.

134 Spain Alba-Sánchez, F., Anderson, R.,
García-Moreiras, I., Jiménez-Moreno, G., Leroy, S., López-Sáez, J.A., MesaFernández, J., Morales-Molino, C., Muñoz Sobrino, C., Ramos-Román, M., Sabariego Ruiz, S.
Antipina et al. (2014, 2016); Aseev, 1959; Binney et al. (2016, 2017); Blyakharchuk et al. (2007, 2019); Blyakharchuk and Chernova (2013); Borisova et al. (2011); Bukreeva et al., 1986; Duguay et al. (2012); Hijmans et al. (2005); Ivanov and Ryabogina (2004); Klemm et al. (2013, 2016); Kosintsev et al. (2010); Lapteva (2009); Lapteva et al. (2013); Lapteva (2013); Lapteva et al. (2017); Lapteva and Korona (2012); Larin and Ryabogina (2006); Lopatina and Zanina (2016); Lychagina et al. (2013); Makovsky and Panova, 1978; Matishov et al. (2011); Matveev et al., 1997; Matveeva et al. (2003); Mikishin and Gvozdeva (2009, 2012); Müller et al. (2010); Naidina and Richards (2018); Nepomilueva and Duryagin, 1990; Niemeyer et al. (2017); Nikiforova (1978); Novenko et al. (2011, 2014, 2017); Panova, 1981; Panova et al., (1996, 2010, 2008); Panova and Korotkovskaya (1990); Panova and Makowski (1979); Petrenko et al. (2009); Poshekhonova et al. (2008); Ryabogina and Orlova (2002); Salonen et al. (2011, 2012); Sapelko and Nosevich (2013); Shavnin et al. (2006); Stivrins et al. (2017b); Surova and Troitsky, 1971; Zakh (1997)

Anderson et al. (2011); García-Moreiras et al. (2015); Jiménez-Moreno et al. (2013); Jiménez-Moreno and Anderson (2012); Leroy, 1990; Mesa-Fernández et al. (2018); Morales-Molino et al. (2017a, b, 2018, 2011, 2013); Morales-Molino and García-Antón (2014); Muñoz Sobrino et al. (2014); Ramos-Román et al. (2016,2018)

\begin{tabular}{llll}
\hline 4 & Sweden & Nielsen, A., Åkesson, C. & Åkesson et al. (2015); Ning et al. (2018) \\
\hline 29 & Tunisia & Desprat, S., Gaceur, E. & Gaceur et al. (2017) \\
\hline 31 & Turkey & Shumilovskikh, L. & Binney et al. (2016, 2017) \\
\hline 2 & Ukraine & Binney, H., Borisova, O. & \\
\hline 18 & United & Bunting, M. & \\
\hline
\end{tabular}


Some large independent surface sample datasets covering the Eurasian region have been published and made available since EMPD1, most notably Binney et al. (2017), Marinova et al. (2018), and Herzschuh et al. (2019). Both Binney et al. (2017) and Marinova et al. (2018) already include a large amount of data from the EPD and EMPD1, but also data that have not been publicly released before. This includes "heritage" data from earlier studies such as the Biome6000 project Prentice and Webb, 1998) and PAIN project (Bigelow et al., 2003). These heritage data are mostly composed of percentages, at least some (unknown part) of which have been digitised, and whose origins, selection criteria, and context are rarely documented. Another problem with these heritage data apart from the limited metadata is the loose definition of a "modern sample" in these early projects, being defined in both PAIN and Biome6000 as anything younger than $500 \mathrm{BP}$. Unfortunately, the age criteria for selecting individual samples were not recorded when the datasets were compiled.

These problems also extend to the recent release of data by Herzschuh et al. (2019) from China and Mongolia. These data represent most of the modern pollen data held in the Chinese Pollen Database (CPD) (Ni et al., 2010; Zheng et al., 2014). The Herzschuh et al. (2019) dataset includes 2559 modern pollen samples and is of major importance as the first significant amount of publicly available data from this region. However, the data are only provided as percentages based on a summary of the taxa from each sample and also include digitised data. We were therefore unable to include it in the EMPD2. The Herzschuh et al. (2019) data are available from PANGAEA, along with the Tarasov et al. (2011) dataset of 798 samples mainly from Japan and eastern Russia, which are also provided as percentages for a limited selection of taxa. We hope that the raw count data for the full assemblage will be made available in the near future.

Other regional pollen databases that overlap with the EMPD include the Indian Pollen Database (IPD) and the African Pollen Database (APD). The IPD is still under development and is not publicly accessible, but it includes both fossil and modern pollen samples from the Indian subcontinent (Krishnamurthy and Gaillard, 2011). The EMPD also includes samples from North Africa, which overlaps with the APD (Vincens et al., 2007). Fossil pollen data from the APD are available as individual files and as a partially complete paradox database from the APD website (Table 3), but the status of the modern pollen data held within the APD (Gajewski et al., 2002) remains somewhat unclear, since these data have not been made publicly available. At present the APD is being integrated into Neotoma, and it is hoped that once this is completed the modern pollen data from Africa will become more freely available.

\subsection{Data processing}

As with the EMPD1, the data submitted to the EMPD2 have come in a wide variety of data formats and with varying lev-
Table 3. Web addresses for pollen databases mentioned in the text. Last access of all URLs: 20 January 2020.

\begin{tabular}{lc}
\hline Eurasian Modern Pollen Database (EMPD) \\
\hline $\begin{array}{l}\text { Viewer: } \\
\text { Data link: }\end{array}$ & $\begin{array}{l}\text { https://empd2.github.io/?branch=master } \\
\text { https:/epdweblog.org/ } \\
\text { european-modern-pollen-database/ }\end{array}$ \\
\hline European Pollen Database (EPD)
\end{tabular}

els of metadata. All of these files had to be processed and a variety of quality control checks made before entry into the database (see also Davis et al., 2013).

Figure 1 shows the steps taken in processing and qualitycontrolling the data. On receipt from the contributor, the data were entered into one of two standardised file formats according to whether they were pollen data or the associated metadata. Each of the two different types of data was then subject to a series of quality control checks to make sure they did not contain errors and that they conformed to data protocols. For instance, values in numerical fields in the metadata (shown in Table 1) had to fall within realistic boundaries expected for that field, such as for latitude, longitude, and altitude. Also, it had to be checked that controlled fields based on selection from a list of acceptable classes did not contain assignment errors, such as country name. Any missing entries were referred back to the contributor for completion, or else were completed from the original publication or other information source where available.

One of the most time-consuming tasks with the pollen data was to ensure standardisation of the original taxon names submitted by the contributor. These all had to be checked for language, typographical errors, and other issues and then assigned an internationally accepted taxa name according to the EPD common taxa "p_vars" table. If the name did not exist in the EPD taxa table it was checked (using http: //www.theplantlist.org/, last access: 20 January 2020) that it was spelled correctly and was not a synonym. It was then 
checked against the Neotoma pollen taxa table and assigned the Neotoma-accepted taxa name if there was a match. If it was not in the Neotoma taxa table, and it was established to be a genuine taxa name, then it was added to the EMPD taxa table as a new taxon. Note that although the EMPD is designed to be as compatible with the EPD as possible, the EMPD and EPD do not have a common taxa list, and the EMPD has many more taxa than appear in the EPD.

The accepted names for the fossil data in the EPD or Neotoma should be directly compatible with the accepted names in the EMPD, but some caution needs to be applied in integrating the two datasets since the EMPD contains additional accepted names that do not occur in the EPD or Neotoma. Where possible the EMPD assignment of accepted names respects the taxonomic resolution of the EPD- and Neotoma-accepted names. This means that where a new original taxa name is submitted to the EMPD that does not already occur in the existing databases, it is assigned the EPDor Neotoma-accepted name according to the existing taxonomic hierarchy. For example, if the new submitted original taxa name is a new species that does not occur in the EPD or Neotoma, and there is an existing accepted name at genus level, then the new species name is assigned the accepted name at the genus level. The assignment of accepted names is complicated because it requires an appreciation of differences in pollen morphology and of the reliability of identification, which can vary given the differences in skill and experience of the different analysts who contribute to the database. In addition, there are also important geographical considerations to take into account. For instance, the EMPD conforms to the EPD-accepted names but these are heavily European orientated, while the EMPD has much more data from regions such as eastern Asia where some of the accepted names are not strictly appropriate. However, in all cases we have retained in the EMPD all of the original taxa names as they were submitted by the original contributor after cleaning for typographical errors.

In the process of updating the EMPD we have harmonised as much as possible the taxa names in the EMPD with those found in the current EPD, including those names previously in the EMPD1 that have since been included in the EPD. When both the EPD and EMPD are included in the Neotoma database, then all of the taxa will exist in a single standardised taxa table consisting of all of the taxa in all of the databases.

Once the pollen data and metadata entry tables had been manually completed and checked, these were then uploaded into a Postgres database where a second series of automated quality control procedures were undertaken. These automated checks repeated many of the earlier manual checks, including ensuring that all open and closed fields were correctly completed and that the taxa names conformed to the database standardised taxa names (the "p_vars" table). In addition, it was also necessary to manually standardise worker names, address details, and data references across different datasets submitted to the database.

After the data had passed these database checks, each contributor was then asked to look again at their data as they were now stored in the database. Contributors were able to do this using the online data viewer, which provided an intuitive interface to the database that could be navigated without any prior experience of database systems. Locations for each site/sample could be checked using the viewer map interface, pollen data could be checked using a graphical (histogram) display, and metadata could be checked using a table view of all of the metadata fields. Any issues highlighted by the contributors were then corrected in the database. It was only after completing these final contributor checks that the EMPD2 database was deemed suitable for public release.

As well as adding new data, we also undertook a short review of the data in the original EMPD1. A cross-check between the country attributed to a site and the actual country where the site was located revealed that around 20 sites had either the wrong location or wrong country code. The geolocation data for around 250 samples in Morocco in EMPD1 have now been removed and placed in the information field. These were all highlighted in EMPD1 as having intractable geolocation errors (Davis et al., 2013), and it was felt that by removing the corrupt information from the geolocation field it would discourage their accidental use. In compensation the EMPD2 now includes new high-quality data from Morocco (see next section).

\section{Results}

\subsection{Spatial sampling}

The amount of data in the database has increased by $60 \%$, and the EMPD2 now holds 8134 samples compared to 4826 samples in the EMPD1. The country that has experienced the largest increase in samples is Russia, which has gained 2274 more samples on top of the 379 samples already in the EMPD1 (Fig. 1). Other significant improvements in data coverage have been made in Italy, Norway, and Spain, while data are available for the first time from other countries such as Japan, Cyprus, and Kyrgyzstan. The increase in data from Russia reflects a general improvement in data coverage in EMPD2 from eastern Europe across to Asia (Fig. 2), prompting a renaming of the database from the "European" to the "Eurasian" Modern Pollen Database.

Countries where there are still relatively few or no samples despite being both relatively populous and having an active palynological community include Belgium, the Netherlands, Hungary, Czech Republic, and Slovakia. There are also virtually no samples from the Balkans. Despite the generally excellent coverage over Scandinavia, north-central Sweden remains poorly sampled, a feature that is also reflected in the lack of fossil pollen data from this area in the EPD. Further east, the distribution of samples tends to be best in 


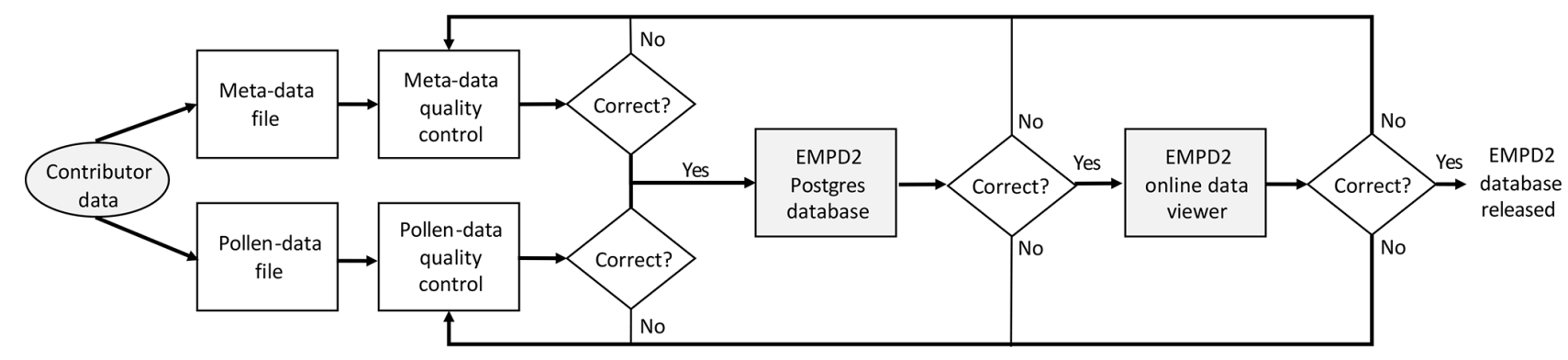

Figure 1. A flow diagram showing the data processing and quality control steps taken in constructing the EMPD2 database.

the more populous regions and those with better transport infrastructure. Notable areas across northern Eurasia where we still lack samples include the steppes of Ukraine and Kazakhstan and the Central Siberian Plateau. Further south, most of China and Mongolia are well covered by the Chinese Pollen Database (now partly released by Herzschuh et al., 2019), and as mentioned earlier, there are efforts in India to improve data coverage in this region. A more difficult problem is the lack of samples from many of the Central Asian countries including Turkmenistan, Uzbekistan, Tajikistan, Afghanistan, and to some extent Pakistan, where access for scientists is currently difficult or hazardous, and where there are few locally trained scientists. The lack of modern pollen data from these regions is also reflected in a lack of fossil pollen studies from these countries.

\subsection{Altitudinal sampling}

The representativeness of the sample coverage in the vertical spatial domain is not easily discernible from a standard twodimensional map presented in Fig. 3. Vertical climate and vegetation gradients are much steeper than horizontal gradients, and hilly and mountainous terrain typically holds a greater variety of vegetation and climate types than can be shown on a continental-scale map. We make a better attempt to show this by plotting the distribution of samples by altitude on a hypsometric (or cumulative frequency) curve for the Palearctic study region (Fig. 4). This shows that the number of samples generally follows the proportion of land area represented at each elevation, with more samples at lower altitude, but there is still the presence of samples as the altitude gets higher. Data coverage has improved in particular in the 500-2500 m range between EMPD1 and EMPD2. The upper part of the altitudinal range above $3500 \mathrm{~m}$ is dominated by the Himalayas and the Tibetan Plateau, which is covered by the Chinese Pollen Database (Herzschuh et al., 2019).

\subsection{Climate and vegetation sampling}

The distribution of the EMPD2 samples across the vegetation biomes of the region (from Olson et al., 2001) is shown in Fig. 4. Biomes that are well sampled within the Palearctic region include most of those that occur in Europe, namely
Mediterranean scrub and temperate forests and the western range of the boreal forest/taiga and tundra. Less well sampled are the temperate shrub and grasslands and deserts of the Central Asian steppe, and the eastern range of the boreal forest/taiga and tundra. Again, the Chinese Pollen Database (Herzschuh et al., 2019) covers much of the montane biomes of the Himalayas and Tian Shan, the grasslands and deserts of the Gobi area and Mongolia, and temperate and tropical forest biomes of East Asia.

While a conventional map such as Fig. 5a can show how samples are distributed across different biomes in geographical space, it does not show how well those samples are distributed in climate space. Large areas of Earth may have the same or similar climate, and the distribution of samples in conventional space does not necessarily equate to how well climate space has been sampled. Climate space is important because pollen-based climate reconstructions depend on the use of modern pollen calibration datasets that fully sample the available climate space associated with any particular vegetation type. Figure $5 \mathrm{~b}$ shows the same information as Fig. 5a, but this time in climate space. This indicates that the EMPD2 samples appear better distributed in climate space than geographical space, but that there are fewer samples to represent the more extreme climates found at the edges of the modern climate space (such as tundra, deserts, and xeric scrublands). This is shown more clearly in Fig. 6b, where the Euclidean distance is calculated between the climate of each of the pollen samples in EMPD2 and all of the available climate space of the Palearctic region. This was done using mean annual temperature and precipitation from the WorldClim2 modern climatology (Fick and Hijmans, 2017), normalised to make the different scales comparable. The climate of the pollen site were assigned according to the nearest grid point within the 30 second (approximately $1 \mathrm{~km}^{2}$ ) resolution of the WorldClim2 grid, whilst the climate of the region was taken from the grid itself. The darker regions around the edges of the climate space show where in climate space the EMPD2 still lacks representative samples. These poorly represented climates are then shown in physical space in Fig. 6a. This indicates poor representation in the North African and Persian deserts, which are outside the Palearctic study region, but also areas within the Palearctic region including the Cen- 


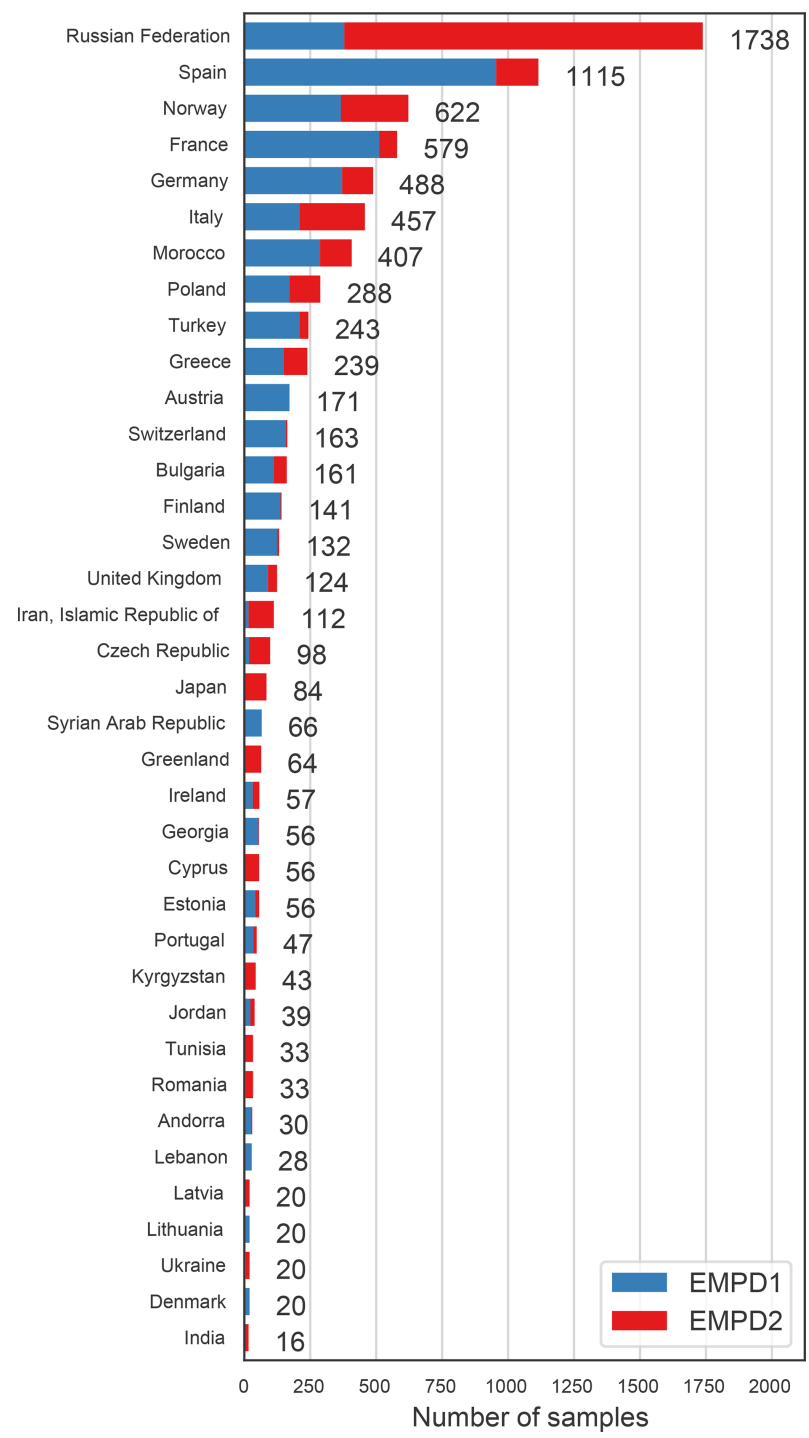

Uzbekistan: $10(0)$, Kazakhstan: $9(0)$, Belgium: $9(9)$, Iceland: $5(1)$, Hungary: $5(3)$, Belarus: 5 (5), Croatia: $4(4)$, marine: $4(0)$, Slovenia: $4(4)$, Slovakia: $3(0)$, Turkmenistan, Republic of: $3(0)$

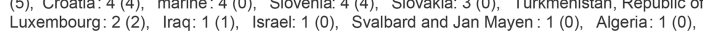
Albania: 1 (1)

Figure 2. A comparison of the number of samples in EMPD versions 1 and 2, by country. Countries with only small numbers of samples are listed at the bottom; values in brackets indicate new samples in EMPD2.

tral Asian steppe and more mountainous areas of the Central Siberian Plateau and Siberia east of Yakutsk $\left(130^{\circ} \mathrm{E}\right)$.

\section{Discussion}

The increase in size of the EMPD in version EMPD2 has greatly improved the coverage of modern pollen samples across Eurasia in relation to geographical, vegetation, and climate space. This will make it possible to create more accurate reconstructions of past land cover and climate given the commensurate improvements in available climate and vege- tation analogues of fossil pollen samples. The database continues to increase in size through a mixture of newly submitted samples from old studies that predate EMPD1 and more recent studies that have occurred since EMPD1 was first made available. It is still likely that older data will continue to be submitted to the database, especially as it becomes better known, but it is unlikely that the database will continue to grow at the present rate given that much of the available older data are now expected to have been submitted. However, surface sample work has traditionally been less likely to be published in international journals, often confined to Masters or $\mathrm{PhD}$ theses or other grey literature, and the amount of data in existence may therefore be difficult to estimate.

To help promote access and use of the EMPD, we have created an online data viewer https://empd2.github.io (last access: 20 January 2020) (Fig. 7) (Sommer et al., 2020). This allows the database to be viewed using an intuitive clickable map that displays the location of each sample, associated metadata, and a plot of the pollen data themselves. It is also possible to download the data associated with a sample and to make suggested corrections. Other options allow the user to select subsets of the database to be viewed, for instance associated with particular individuals, projects, or research groups. The EMPD viewer allows access to the database in an intuitive way without requiring any particular computer expertise. This has been very important in not only allowing the casual user to view and access the data in the database, but also in allowing the data submitters to view their data as they exist in the database after they have been processed, providing a further quality control check. The data viewer is open source and can be adapted for other uses.

The EMPD data viewer is embedded in a web framework that is based on the version control system GitHub, where users and data contributors can transparently submit new data or raise issues with the existing data. These can then be reviewed in an open discussion with the database managers. This framework allows ongoing development of the EMPD in the future, and the usage of a free version control system additionally ensures full transparency, stability, and maintainability of access to the data, independent of funding and changing collaborations.

As well as simply adding more samples as they are submitted, we hope that the future development of the EMPD will also be more targeted. It is clear that although sample coverage is much improved in EMPD2, gaps still exist in the data coverage for Eurasia that would be useful to fill (Figs. 4-6). One way to do this is to encourage fieldwork to collect samples from these data-poor regions. This approach however is expensive, since the reason why many of these areas remain unsampled is precisely because of their remoteness and the difficulty and expense involved in accessing them. An alternative that has not been widely exploited is to analyse soil and sediment samples gathered as a result of fieldwork expeditions organised with a different objective in mind. We hope that by demonstrating the important sampling gaps in the 


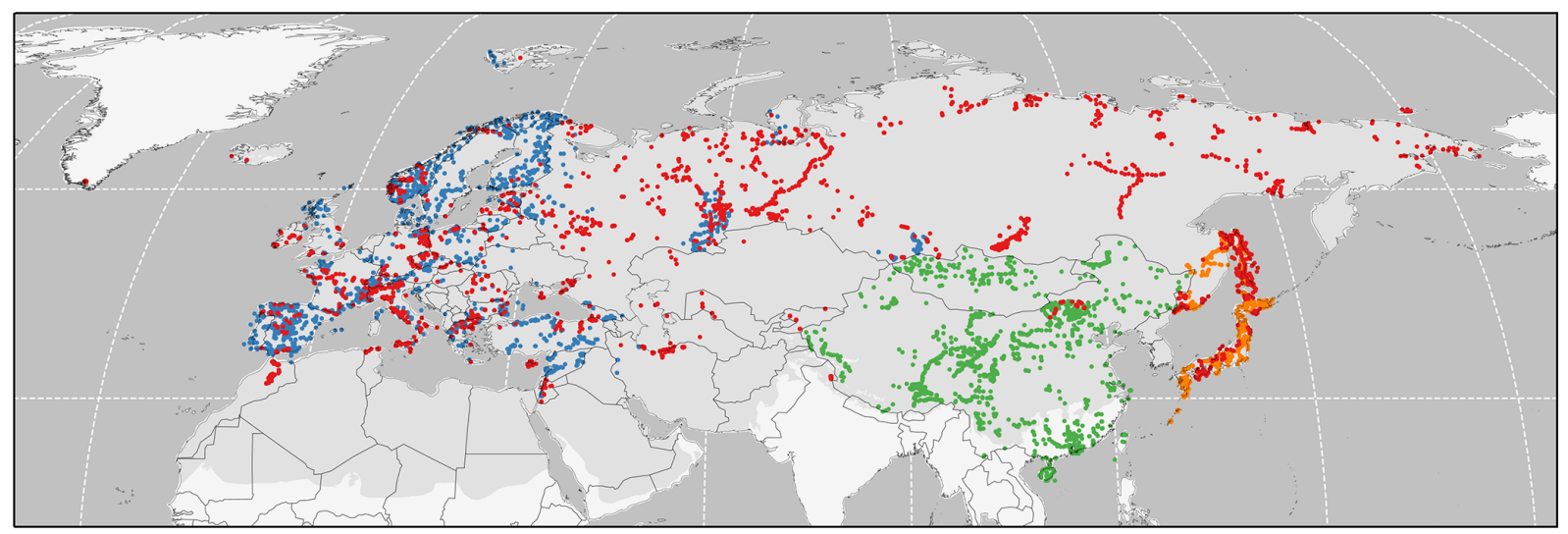

EMPD1 Herzschuh et al. (2019)

Tarasov et al. (2011)

EMPD2

Paleartic region

Figure 3. Map of samples included in EMPD versions 1 and 2 and two other datasets (see text).

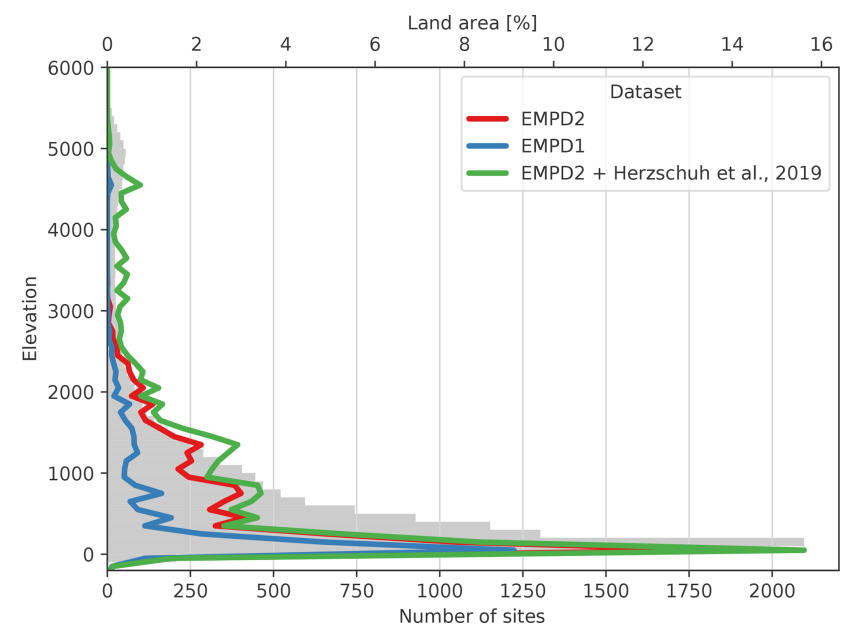

Figure 4. Distribution of samples by altitude for the Palearctic region (compared to land area at each altitude).

database it will encourage individuals and research groups to consider fieldwork and data analysis in these underrepresented regions.

\section{Ethical statement and how to acknowledge the database}

Users of the database are expected to follow the guidelines of the EPD. These state that normal ethics apply to co-authorship of scientific publications. Palaeoecological datasets are labour intensive and complex, they take many years to generate, and they may have additional attributes and metadata not captured in the EMPD/EPD. Users of data stored in the EMPD/EPD should consider inviting the original data contributor of any resultant publications if that contributor's data are a major portion of the dataset analysed, or if a data contributor makes a significant contribution to the analysis of the data or to the interpretation of results. For large-scale studies using many EMPD/EPD records, contacting all contributors or making them co-authors will not be practical, possible, or reasonable. Under no circumstance should authorship be attributed to data contributors, individually or collectively, without their explicit consent.

In all cases, any use of EMPD data should include the following or similar text in the acknowledgements: "Pollen data were extracted from the Eurasian Modern Pollen Database (part of the European Pollen Database), and the work of the data contributors and the EMPD/EPD community is gratefully acknowledged." Upon publication, please send to the EMPD/EPD a copy of the published work or a link to the electronic resource. Your assistance helps document the usage of the database, which is critical to ensure continued support from funders and contributors.

\section{Data availability}

The EMPD is available at https://doi.org/10.1594/PANGAEA.909130 (Chevalier et al., 2019). The data are available as (1) an Excel spreadsheet, (2) a PostgreSQL dump, and (3) a SQLite3 portable database format. The data can also be viewed online using an interactive map-based viewer at https://empd2.github.io/?branch=master (last access: 20 January 2020).

\section{Conclusions}

The EMPD remains the only public, quality-controlled, and standardised database of modern pollen samples for the Eurasian region. This paper describes a recent update to the EMPD in which the database has increased almost $60 \%$ in 
(a)

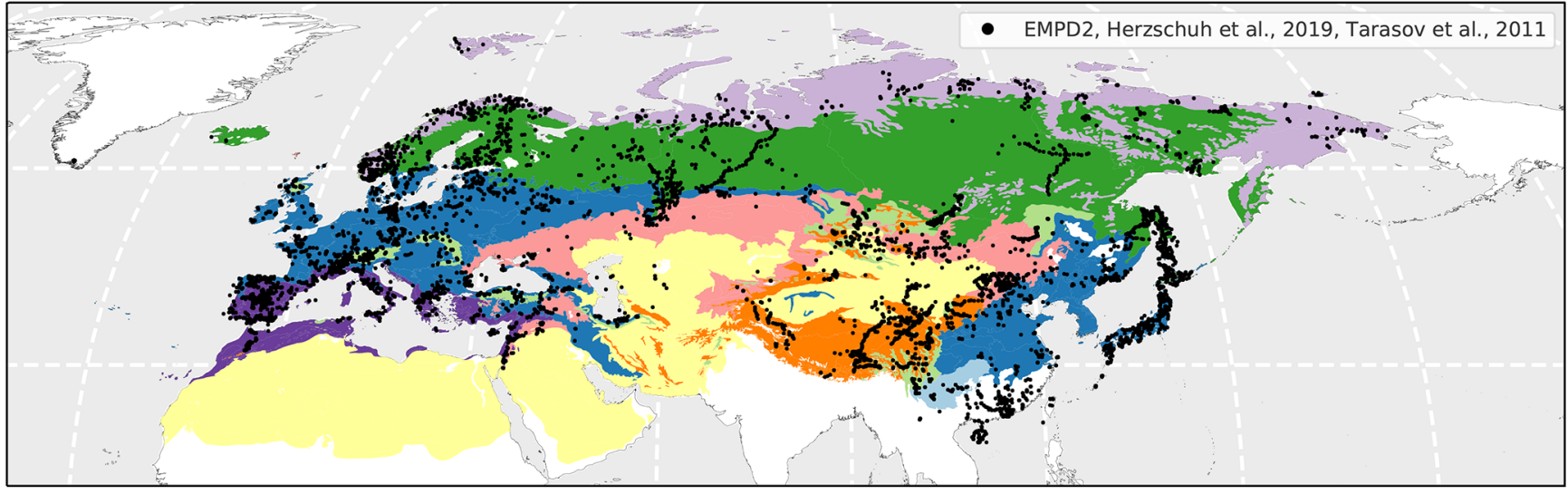

\begin{tabular}{lll}
\multicolumn{2}{c}{ Biome } \\
Tropical and subtropical moist broadleaf forests & Montane grasslands and shrublands \\
Temperate broadleaf and mixed forests & & Tundra \\
Temperate coniferous forest & Mediterranean forests, woodlands, and scrubs \\
Boreal forests / taiga & & Deserts and xeric shrublands \\
Temperate grasslands, savannas, and shrublands &
\end{tabular}

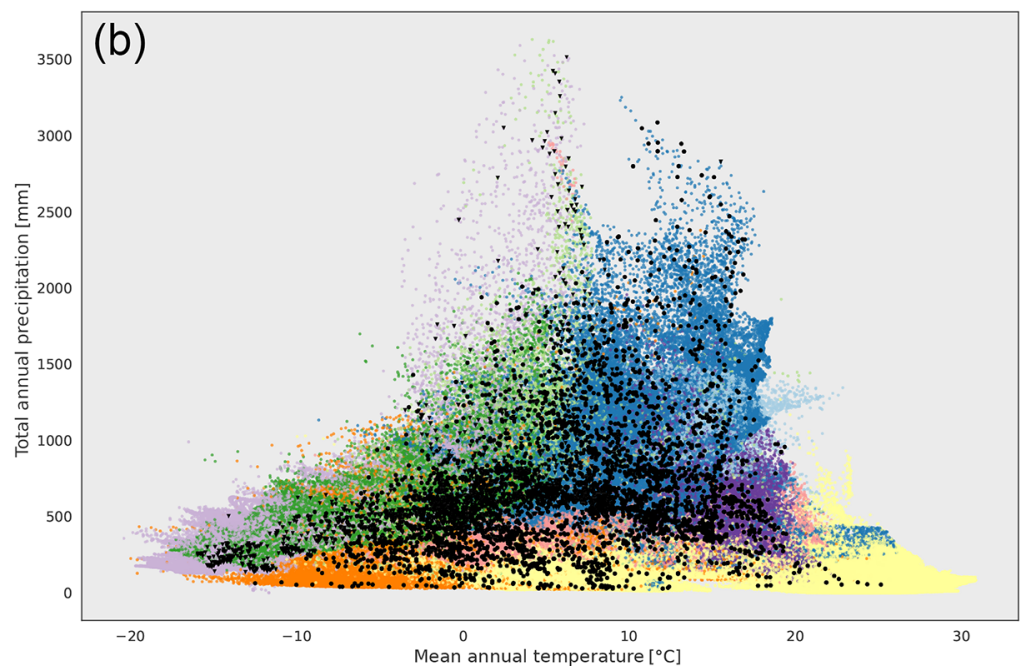

Figure 5. (a) Biome map and sample locations. (b) Biomes and samples in climate space. Biome data from Olson et al. (2001)

size, so that it now contains data on 8663 modern pollen samples. This reflects an expansion in spatial coverage across northern and eastern Asia, which has prompted a change in the name of the database from the European to the Eurasian Modern Pollen Database. The improvement in spatial coverage has increased the number of vegetation and climate analogues for fossil pollen samples in the region that will directly improve reconstructions of past vegetation and climate. However, areas of poor data coverage still exist, particularly in the more remote regions of central and northern Asia and the Middle East. Development of a new map-based online data viewer for the database is already helping im- prove access to, and participation in, the EMPD, as well as quality control. We expect the EMPD to continue to grow in the future, although probably at a slower rate given that most of the previously published "heritage" data have now been incorporated. At present the EMPD remains associated with, but physically independent of, the EPD. It is also subject to only periodic updates. In future we expect both the EPD and EMPD to become fully incorporated into the global Neotoma Palaeoecological Database, which will provide seamless integration of the fossil and modern data, whilst also allowing continual updates using Neotoma data management tools. 

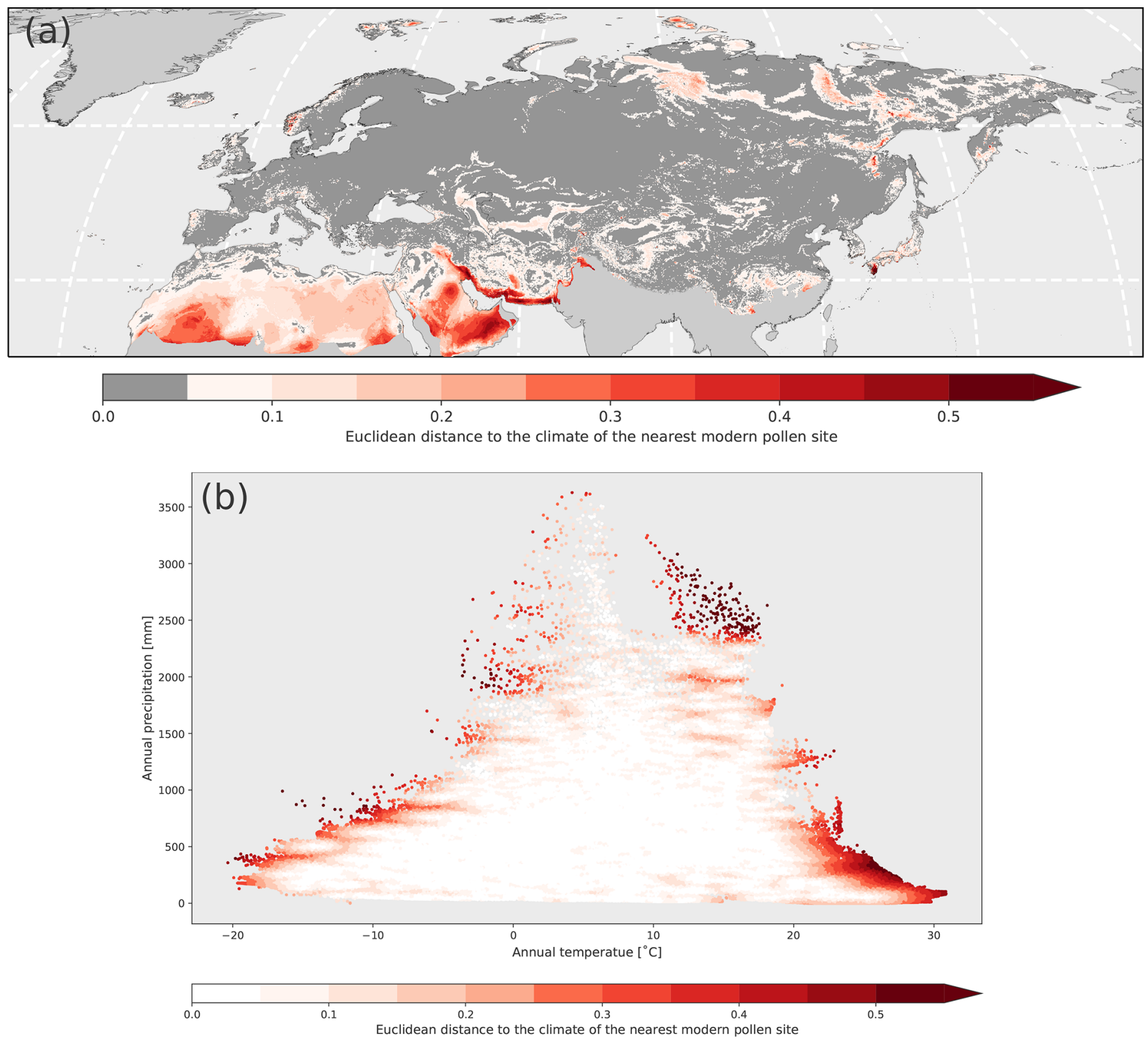

Figure 6. (a) The Euclidian distance between the climate of each modern pollen sample location (as shown in Fig. 3) and the climate of the entire Palearctic region. (b) The same as (a) but shown in climate space. Note that for clarity the values $<0.05$ are shown by dark grey in (a), but white in (b). The darker the brown shading, the less well that climate is represented amongst the samples. The climate of each pollen site was assigned according to the nearest grid point within the $30 \mathrm{~s}$ (approximately $1 \mathrm{~km}^{2}$ ) resolution of the WorldClim 2 grid, whilst the climate of the region was taken from the grid itself. 


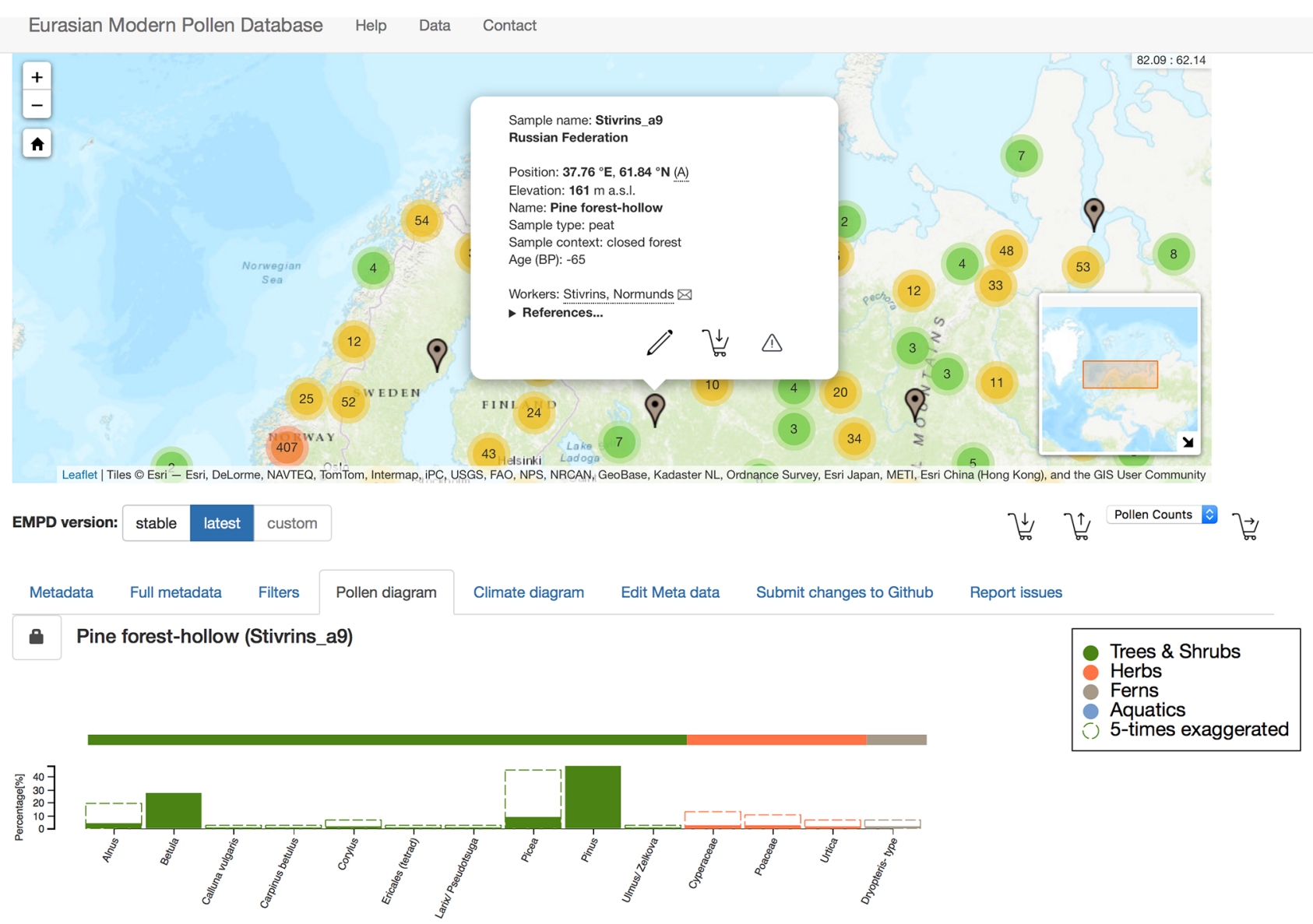

Figure 7. Screen grab of the EMPD online data viewer (available at https://empd2.github.io, last access: 20 January 2020).

Author contributions. BASD wrote the manuscript with input from all of the authors. BASD, MC, and PS designed and implemented the database and data viewer. BASD, MC, PS, MZ, WF, LNP, AM, and VC all helped with data processing. All of the remaining authors contributed pollen sample data and were involved in the original collection, preparation, identification, and counting of these data.

Competing interests. The authors declare that they have no conflict of interest.

Acknowledgements. The EMPD includes data obtained from the Neotoma Palaeoecology Database and the European Pollen Database. The work of the data contributors and the scientific community supporting these databases is gratefully acknowledged.

Financial support. This research has been supported by the Swiss National Science Foundation (grant no. 200021_169598), with additional support from the University of Lausanne.
Review statement. This paper was edited by Thomas Blunier and reviewed by two anonymous referees.

\section{References}

Abbate, G.: Studio delle tipologie fitosociologiche del Monte Soratte Lazio e loro contributo nella definizione fitogeografica dei complessi vegetazionali centro-appenninici, Consiglio Nazionale delle Ricerche, 1981.

Åkesson, C., Nielsen, A. B., Broström, A., Persson, T., Gaillard, M.-J., and Berglund, B. E.: From landscape description to quantification: A new generation of reconstructions provides new perspectives on Holocene regional landscapes of SE Sweden, The Holocene, 25, 178-193, https://doi.org/10.1177/0959683614556552, 2015.

Anderson, R. S., Jiménez-Moreno, G., Carrión, J. S., and Pérez-Martínez, C.: Postglacial history of alpine vegetation, fire, and climate from Laguna de Río Seco, Sierra Nevada, southern Spain, Quat. Sci. Rev., 30, 1615-1629, https://doi.org/10.1016/j.quascirev.2011.03.005, 2011.

Antipina, T. G., Panova, N. K.. and Korona, O. M.: The holocene dynamics of vegetation and environmental conditions on the 
eastern slope of the Northern Urals, Russ. J. Ecol., 45, 351-358, https://doi.org/10.1134/S1067413614050026, 2014.

Antipina, T. G., Panova, N. K.. and Chairkina, N. M.: Dynamics of the natural environment in the Holocene according to the data of the complex analysis of the VI Section of the Gorbunovsky peat bog, Izv. Komi nauchnogo tsentra UrO RAN, 89-97, 2016.

Aseev, A. A.: Paleogeography of the Middle and Lower Oka Valley in the Quaternary Period, Akad. Nauk SSSR, Moscow, 1959.

Atanassova, J. R.: Pollen deposition in moss polsters and pollen traps in the Central Stara Planina Mts (2002-2005), Phytol. Balc., 13, 223-228, 2007.

Beer, R., Tinner, W., Carraro, G., and Grisa, E.: Pollen representation in surface samples of the Juniperus , Picea and Juglans forest belts of Kyrgyzstan, central Asia, The Holocene, 17, 599-611, https://doi.org/10.1177/0959683607078984, 2007.

Bell, B. A. and Fletcher, W. J.: Modern surface pollen assemblages from the Middle and High Atlas, Morocco: insights into pollen representation and transport, Grana, 55, 286-301, https://doi.org/10.1080/00173134.2015.1108996, 2016.

Bigelow, N., Brubaker, L., Edwards, M., Harrison, S., Prentice, I., Andreson, P., and Andreev, A.: Climate change and Arctic ecosystems I: Vegetation changes north of 55, J. Geophys. Res., 108, 8170, https://doi.org/10.1029/2002JD002558, 2003.

Binney, H. A., Lozhkin, A. V., Anderson, P., Andreev, A. A., Bezrukova, E., Blyakharchuk, T., Jankovska, V., Khazhina, I., Krivonogov, S., Kremenetski, K. V., Novenko, E. Y., Ryabogina, N., Solovieva, N., and Zernitzkaya, V.: Eurasian pollen data from 21 kiloannum to the present, NERC Environmental Information Data Centre, https://doi.org/10.5285/6aeba247-52d1-4e84-949f603742af40c1, 2016.

Binney, H. A., Edwards, M., Macias-Fauria, M., Lozhkin, A., Anderson, P., Kaplan, J. O., Andreev, A. A., Bezrukova, E., Blyakharchuk, T., Jankovska, V., Khazina, I., Krivonogov, S., Kremenetski, K. V., Nield, J., Novenko, E. Y., Ryabogina, N., Solovieva, N., Willis, K. J., and Zernitskaya, V. P.: Vegetation of Eurasia from the last glacial maximum to present: Key biogeographic patterns, Quat. Sci. Rev., 157, 80-97, https://doi.org/10.1016/j.quascirev.2016.11.022, 2017.

Blyakharchuk, T. and Chernova, N. A.: Vegetation and climate in the Western Sayan Mts according to pollen data from Lugovoe Mire as a background for prehistoric cultural change in southern Middle Siberia, Quat. Sci. Rev., 75, 22-42, https://doi.org/10.1016/j.quascirev.2013.05.017, 2013.

Blyakharchuk, T., Wright, H. E., Borodavko, P. S., van der Knaap, W. O., and Ammann, B.: Late Glacial and Holocene vegetational history of the Altai Mountains (southwestern Tuva Republic, Siberia), Palaeogeogr. Palaeoclimatol. Palaeoecol., 245, 518-534, https://doi.org/10.1016/j.palaeo.2006.09.010, 2007.

Blyakharchuk, T., Prikhodko, V., Kilunovskaya, M., and Li, H.C.: Vegetation and climate reconstruction based on pollen and microbial records derived from burial mounds soil in Tuva Republic, Central Asia, Quat. Int., 507, 108-123, https://doi.org/10.1016/j.quaint.2018.09.028, 2019.

Borisova, O. K., Novenko, E. Y., Zelikson, E. M., and Kremenetski, K. V.: Lateglacial and Holocene vegetational and climatic changes in the southern taiga zone of West Siberia according to pollen records from Zhukovskoye peat mire, Quat. Int., 237, 6573, https://doi.org/10.1016/j.quaint.2011.01.015, 2011.
Bukreeva, G. F., Votakh, M. P., and Bishaev, A. A.: Opredelenie paleoklimatov po palinologicheskim dannym [Determination of Paleoclimates on the Basis of Palynological Data], Institute of Geology and Geophysics, Novosibirsk, 1986.

Caseldine, C. and Pardoe, H. S.: Surface pollen studies from alpine/sub-alpine southern Norway: applications to Holocene data, Rev. Palaeobot. Palynol., 82, 1-15, https://doi.org/10.1016/0034-6667(94)90016-7, 1994.

Chevalier, M., Davis, B. A. S., Sommer, P. S., Zanon, M., Carter, V. A., Phelps, L. N., Mauri, A., and Finsinger, W.: Eurasian Modern Pollen Database (former European Modern Pollen Database), Pangaea, https://doi.pangaea.de/10.1594/PANGAEA.909130, 2019.

Davis, B. A. S., Zanon, M., Collins, P., Mauri, A., Bakker, J., Barboni, D., Barthelmes, A., Beaudouin, C., Birks, H.J.B., Bjune, A. E., Bozilova, E., Bradshaw, R. H. W., Brayshay, B. A., Brewer, S., Brugiapaglia, E., Bunting, J., Connor, S. E., de Beaulieu, J.L., Edwards, K., Ejarque, A., Fall, P., Florenzano, A., Fyfe, R., Galop, D., Giardini, M., Giesecke, T., Grant, M. J., Guiot, J., Jahns, S., Jankovská, V., Juggins, S., Kahrmann, M., KarpińskaKołaczek, M., Kołaczek, P., Kühl, N., Kuneš, P., Lapteva, E. G., Leroy, S. A. G., Leydet, M., López Sáez, J. A., Masi, A., Matthias, I., Mazier, F., Meltsov, V., Mercuri, A. M., Miras, Y., Mitchell, F. J. G., Morris, J. L., Naughton, F., Nielsen, A. B., Novenko, E., Odgaard, B., Ortu, E., Overballe-Petersen, M. V., Pardoe, H. S., Peglar, S. M., Pidek, I. A., Sadori, L., Seppä, H., Severova, E., Shaw, H., Świeta-Musznicka, J., Theuerkauf, M., Tonkov, S., Veski, S., van der Knaap, W. O., van Leeuwen, J. F. N., Woodbridge, J., Zimny, M., and Kaplan, J. O.: The European Modern Pollen Database (EMPD) project, Veg. Hist. Archaeobot., 22, 521-530, https://doi.org/10.1007/s00334-0120388-5, 2013.

Di Rita, F. and Magri, D.: Holocene drought, deforestation and evergreen vegetation development in the central Mediterranean: a 5500 year record from Lago Alimini Piccolo, Apulia, southeast Italy, The Holocene, 19, 295-306, https://doi.org/10.1177/0959683608100574, 2009.

Di Rita, F., Simone, O., Caldara, M., Gehrels, W. R., and Magri, D.: Holocene environmental changes in the coastal Tavoliere Plain (Apulia, southern Italy): A multiproxy approach, Palaeogeogr. Palaeoclimatol. Palaeoecol., 310, 139-151, https://doi.org/10.1016/j.palaeo.2011.06.012, 2011.

Di Rita, F., Molisso, F., and Sacchi, M.: Late Holocene environmental dynamics, vegetation history, human impact, and climate change in the ancient Literna Palus (Lago Patria; Campania, Italy), Rev. Palaeobot. Palynol., 258, 48-61, https://doi.org/10.1016/j.revpalbo.2018.06.005, 2018a.

Di Rita, F., Lirer, F., Bonomo, S., Cascella, A., Ferraro, L., Florindo, F., Insinga, D. D., Lurcock, P. C., Margaritelli, G., Petrosino, P., Rettori, R., Vallefuoco, M., and Magri, D.: Late Holocene forest dynamics in the Gulf of Gaeta (central Mediterranean) in relation to NAO variability and human impact, Quat. Sci. Rev., 179, 137152, https://doi.org/10.1016/j.quascirev.2017.11.012, $2018 \mathrm{~b}$.

Djamali, M., de Beaulieu, J.-L., Campagne, P., Andrieu-Ponel, V., Ponel, P., Leroy, S. A. G., and Akhani, H.: Modern pollen rainvegetation relationships along a forest-steppe transect in the Golestan National Park, NE Iran, Rev. Palaeobot. Palynol., 153, 272-281, https://doi.org/10.1016/j.revpalbo.2008.08.005, 2009. 
Duguay, C. R., Soliman, A., Hachem, S., and Saunders, W.: Circumpolar and regional Land Surface Temperature (LST), version 1, with links to geotiff images and NetCDF files (2007-2010), Pangaea, https://doi.org/10.1594/PANGAEA.775962, 2012.

Fall, P. L.: Modern vegetation, pollen and climate relationships on the Mediterranean island of Cyprus, Rev. Palaeobot. Palynol., 185, 79-92, 2012.

Fărcaş, S. and Tanţău, I.: 16. Poiana Ruscă Mountains (Romania): Peşteana peat bog, Grana, 51, 249-251, https://doi.org/10.1080/00173134.2012.700728, 2012.

Feurdean, A. N. and Willis, K. J.: Long-term variability of Abies alba in NW Romania: implications for its conservation management, Divers. Distrib., 14, 1004-1017, https://doi.org/10.1111/j.1472-4642.2008.00514.x, 2008a.

Feurdean, A. N. and Willis, K. J.: The usefulness of a long-term perspective in assessing current forest conservation management in the Apuseni Natural Park, Romania, For. Ecol. Manage., 256, 421-430, https://doi.org/10.1016/j.foreco.2008.04.050, 2008 b.

Feurdean, A. N., Willis, K. J., and Astaloş, C.: Legacy of the past land-use changes and management on the 'natural' upland forest composition in the Apuseni Natural Park, Romania, The Holocene, 19, 967-981, https://doi.org/10.1177/0959683609337358, 2009.

Feurdean, A. N., Liakka, J., Vannière, B., Marinova, E., Hutchinson, S. M., Mosburgger, V., and Hickler, T.: 12,000-Years of fire regime drivers in the lowlands of Transylvania (Central-Eastern Europe): a data-model approach, Quat. Sci. Rev., 81, 48-61, https://doi.org/10.1016/j.quascirev.2013.09.014, 2013.

Feurdean, A. N., Marinova, E., Nielsen, A. B., Liakka, J., Veres, D., Hutchinson, S. M., Braun, M., Timar-Gabor, A., Astaloş, C., Mosburgger, V., and Hickler, T.: Origin of the forest steppe and exceptional grassland diversity in Transylvania (central-eastern Europe), J. Biogeogr., 42, 951-963, https://doi.org/10.1111/jbi.12468, 2015.

Feurdean, A. N., Veski, S., Florescu, G., Vannière, B., Pfeiffer, M., O’Hara, R. B., Stivrins, N., Amon, L., Heinsalu, A., Vassiljev, J., and Hickler, T.: Broadleaf deciduous forest counterbalanced the direct effect of climate on Holocene fire regime in hemiboreal/boreal region (NE Europe), Quat. Sci. Rev., 169, 378-390, https://doi.org/10.1016/j.quascirev.2017.05.024, 2017.

Fick, S. E. and Hijmans, R. J.: WorldClim 2: new 1-km spatial resolution climate surfaces for global land areas, Int. J. Climatol., 37, 4302-4315, https://doi.org/10.1002/joc.5086, 2017.

Finsinger, W., Heiri, O., Valsecchi, V., Tinner, W., and Lotter, A. F.: Modern pollen assemblages as climate indicators in southern Europe, Glob. Ecol. Biogeogr., 16, 567-582, https://doi.org/10.1111/j.1466-8238.2007.00313.x, 2007.

Finsinger, W., Colombaroli, D., De Beaulieu, J.-L., Valsecchi, V., Vannière, B., Vescovi, E., Chapron, E., Lotter, A. F., Magny, M., and Tinner, W.: Early to mid-Holocene climate change at Lago dell' Accesa (central Italy): climate signal or anthropogenic bias?, J. Quat. Sci., 25, 1239-1247, https://doi.org/10.1002/jqs.1402, 2010.

Fletcher, W. J.: Holocene landscape history of southern Portugal, PhD Thesis, University of Cambridge, 2005.

Florenzano, A. and Mercuri, A. M.: Pollen evidence and the reconstruction of plant landscape of the Pantanello area from the 7th to the 1st century BC, The Chora of Metaponto 7: A Greek Sanctuary at Pantanello, University of Texas Press, 2018.
Florenzano, A., Mercuri, A. M., Rinaldi, R., Rattighieri, E., Fornaciari, R., Messora, R., and Arru, L.: The Representativeness of Olea Pollen from Olive Groves and the Late Holocene Landscape Reconstruction in Central Mediterranean, Front. Earth Sci., 5, 85, https://doi.org/10.3389/feart.2017.00085, 2017.

Furlanetto, G., Ravazzi, C., Badino, F., Buchan, M. S., Champvillair, E., and Maggi, V.: Elevational transects of modern pollen samples: Site-specific temperatures as a tool for palaeoclimate reconstructions in the Alps, The Holocene, 29, 271-286, https://doi.org/10.1177/0959683618810395, 2019.

Gaceur, E., Desprat, S., Rouis-Zargouni, I., Hanquiez, V., Lebreton, V., Combourieu Nebout, N., and Kallel, N.: Pollen distribution in surface sediments of the northern Lower Medjerda valley (northeastern Tunisia), Rev. Palaeobot. Palynol., 247, 13-25, https://doi.org/10.1016/j.revpalbo.2017.07.009, 2017.

Gajewski, K., Lézine, A. M., Vincens, A., Delestan, A., and Sawada, M.: Modern climate-vegetation-pollen relations in Africa and adjacent areas, Quat. Sci. Rev., 21, 1611-1631, https://doi.org/10.1016/S0277-3791(01)00152-4, 2002.

Gałka, M., Tobolski, K., Zawisza, E., and Goslar, T.: Postglacial history of vegetation, human activity and lake-level changes at Jezioro Linówek in northeast Poland, based on multi-proxy data, Veg. Hist. Archaeobot., 23, 123-152, https://doi.org/10.1007/s00334-013-0401-7, 2014.

Gałka, M., Tobolski, K., Lamentowicz, Ł., Ersek, V., Jassey, V. E. J., van der Knaap, W. O., and Lamentowicz, M.: Unveiling exceptional Baltic bog ecohydrology, autogenic succession and climate change during the last 2000 years in CE Europe using replicate cores, multi-proxy data and functional traits of testate amoebae, Quat. Sci. Rev., 156, 90-106, https://doi.org/10.1016/j.quascirev.2016.11.034, 2017.

García-Moreiras, I., Sánchez, J. M., and Muñoz Sobrino, C.: Modern pollen and non-pollen palynomorph assemblages of salt marsh and subtidal environments from the Ría de Vigo (NW Iberia), Rev. Palaeobot. Palynol., 219, 157-171, https://doi.org/10.1016/j.revpalbo.2015.04.006, 2015.

Glais, A., Papageorgiou, A. C., Tsiripidis, I., Schaad, D., López Sáez, J. A. and Lespez, L.: The relationship between vegetation and modern pollen assemblages on Mount Paggeo (NE Greece), Lazaroa, 37, 105-123, https://doi.org/10.5209/LAZAROA.53604, 2016.

Grindean, R., Tanţău, I., Fărcaş, S., and Panait, A.: Middle to Late Holocene vegetation shifts in the NW Transylvanian lowlands (Romania), Stud. Univ. Babes-Bolyai, Geol., 59, 29-37, https://doi.org/10.5038/1937-8602.59.1.2, 2014.

Grindean, R., Feurdean, A. N., Hurdu, B., Fărcaş, S., and Tanţău, I.: Lateglacial/Holocene transition to midHolocene: Vegetation responses to climate changes in the Apuseni Mountains (NW Romania), Quat. Int., 388, 76-86, https://doi.org/10.1016/j.quaint.2015.05.056, 2015.

Grudzinska, I., Vassiljev, J., Saarse, L., Reitalu, T., and Veski, S.: Past environmental change and seawater intrusion into coastal Lake Lilaste, Latvia, J. Paleolimnol., 57, 257-271, https://doi.org/10.1007/s10933-017-9945-3, 2017.

Guido, M. A., Montanari, C., and Poggi, G.: Pollen deposition in country villages of Eastern Liguria (Northern Italy), Aerobiologia (Bologna), 8, 148-156, https://doi.org/10.1007/BF02291343, 1992. 
Haghani, S., Leroy, S. A. G., Wesselingh, F. P., and Rose, N. L.: Rapid evolution of coastal lagoons in response to human interference under rapid sea level change: A south Caspian Sea case study, Quat. Int., 408, 93-112, https://doi.org/10.1016/j.quaint.2015.12.005, 2016.

Helena, S.: Vývoj vegetace na úpském raselinisti v Holocénu/Development of the vegetation on Úpské raseliniste Mire in the Holocene, Opera Corcon., 124 pp., 2004.

Herzschuh, U., Cao, X., Laepple, T., Dallmeyer, A., Telford, R. J., Ni, J., Chen, F., Kong, Z., Liu, G., Liu, K. B., Liu, X., Stebich, M., Tang, L., Tian, F., Wang, Y., Wischnewski, J., Xu, Q., Yan, S., Yang, Z., Yu, G., Zhang, Y., Zhao, Y., and Zheng, Z.: Position and orientation of the westerly jet determined Holocene rainfall patterns in China, Nat. Commun., 10, 2376 , https://doi.org/10.1038/s41467-019-09866-8, 2019.

Hijmans, R. J., Cameron, S. E., Parra, J. L., Jones, P. G., and Jarvis, A.: Very high resolution interpolated climate surfaces for global land areas, Int. J. Climatol., 25, 1965-1978, https://doi.org/10.1002/joc.1276, 2005.

Hjelle, K. L. and Sugita, S.: Estimating pollen productivity and relevant source area of pollen using lake sediments in Norway: How does lake size variation affect the estimates?, The Holocene, 22, 313-324, https://doi.org/10.1177/0959683611423690, 2012.

Hjelle, K. L., Mehl, I. K., Sugita, S., and Andersen, G. L.: From pollen percentage to vegetation cover: evaluation of the Landscape Reconstruction Algorithm in western Norway, J. Quat. Sci., 30, 312-324, https://doi.org/10.1002/jqs.2769, 2015.

Ivanov, S. N. and Ryabogina, N.: Reconstruction of natural conditions and palynostratigraphic correlation of archaeological deposits of the Lower Tobol River, Probl. Hum. Interact. Nat. Environ. Tyumen., 5, 73-78, 2004.

Jahns, S.: Untersuchungen über die Vegetationsgeschichte von Süddalmatien und Südgriechenland, Dissertation University of Gøttingen, Cuvillier, Gøttingen, 1992.

Jiménez-Moreno, G. and Anderson, R. S.: Holocene vegetation and climate change recorded in alpine bog sediments from the Borreguiles de la Virgen, Sierra Nevada, southern Spain, Quat. Res., 77, 44-53, https://doi.org/10.1016/j.yqres.2011.09.006, 2012.

Jiménez-Moreno, G., García-Alix, A., Hernández-Corbalán, M. D., Anderson, R. S., and Delgado-Huertas, A.: Vegetation, fire, climate and human disturbance history in the southwestern Mediterranean area during the late Holocene, Quat. Res., 79, 110-122, https://doi.org/10.1016/j.yqres.2012.11.008, 2013.

Joannin, S., Brugiapaglia, E., de Beaulieu, J.-L., Bernardo, L., Magny, M., Peyron, O., Goring, S., and Vannière, B.: Pollenbased reconstruction of Holocene vegetation and climate in southern Italy: the case of Lago Trifoglietti, Clim. Past, 8, 19731996, https://doi.org/10.5194/cp-8-1973-2012, 2012.

Klemm, J., Herzschuh, U., Pisaric, M. F. J., Telford, R. J., Heim, B., and Pestryakova, L. A.: A pollen-climate transfer function from the tundra and taiga vegetation in Arctic Siberia and its applicability to a Holocene record, Palaeogeogr. Palaeoclimatol. Palaeoecol., 386, 702-713, https://doi.org/10.1016/j.palaeo.2013.06.033, 2013.

Klemm, J., Herzschuh, U., and Pestryakova, L. A.: Vegetation, climate and lake changes over the last 7000 years at the boreal treeline in north-central Siberia, Quat. Sci. Rev., 147, 422-434, https://doi.org/10.1016/j.quascirev.2015.08.015, 2016.
Kosintsev, P. A., Lapteva, E. G., Trofimova, S. S., Zanina, O. G., Tikhonov, A. N., and van der Plicht, J.: The intestinal contents of a baby woolly mammoth (Mammuthus primigenius Blumenbach, 1799) from the Yuribey River (Yamal Peninsula), Dokl. Biol. Sci., 432, 209-211, https://doi.org/10.1134/S0012496610030129, 2010.

Krishnamurthy, A. and Gaillard, M.-J.: Land-cover reconstructions in the monsoon affected tropical world: Pollen modeling approach and data synthesis, PAGES news, 19, 89-90, https://doi.org/10.22498/pages.19.2.89, 2011.

Lapteva, E. G.: Landscape-climatic changes on the eastern macroslope of the Northern Urals over the past 50000 years, Russ. J. Ecol., 40, 267-273, https://doi.org/10.1134/S1067413609040079, 2009.

Lapteva, E. G.: Subfossil pollen spectra of modern vegetation in southern urals, Vestn. Bashkirskogo Univ., 18 pp., 2013.

Lapteva, E. G. and Korona, O. M.: Holocene vegetation changes and anthropogenic influence in the forest-steppe zone of the Southern Trans-Urals based on pollen and plant macrofossil records from the Sukharysh cave, Veg. Hist. Archaeobot., 21, 321-336, https://doi.org/10.1007/s00334-011-0333-z, 2012.

Lapteva, E. G., Ektova, S. N., Trofimova, S. S., and Korona, O. M.: Comparative floristic analysis of recent plant macrofossil complexes and subrecent pollen spectra from subarctic tundra of the Yamal penunsula., Biodivers. Far North Ecosyst. Invent. Monit. Prot. Reports II Russ. Sci. Conf. Inst. Biol. Komy Sci. Centre, Syktyvkar, 81-92, 2013.

Lapteva, E. G., Zaretskaya, N. E., Kosintsev, P. A., Lychagina, E. L., and Chernov, A. V.: First data on the Middle to Late Holocene dynamics of vegetation in the Upper Kama region, Russ. J. Ecol., 48, 326-334, https://doi.org/10.1134/S1067413617040099, 2017.

Larin, S. I. and Ryabogina, N.: Towards a history of the development of bog ecosystems of the subtaiga Ishim basin in the Holocene, Geoecol. Probl. Tyumen Reg., 2, 234-245, 2006.

Lazarova, M., Petrova, M., and Jordanova, M.: Pollen monitoring in surface samples in mosses and pollen traps from the Beglika region (W Rhodopes), Phytol. Balc., 12, 317-326, 2006.

Lechterbeck, J.: Human Impact oder Climatic Change? Zur Vegetationsgeschichte des Spätglazials und Holozäns in hochaufløsenden Pollenanalysen laminierter Sedimente des Steisslinger Sees (Südwestdeutschland), Institut und Museum für Geologie und Paläontologie der Universität Tübingen, 2001.

Leipe, C., Demske, D., Tarasov, P. E., Wünnemann, B., and Riedel, F.: Potential of pollen and non-pollen palynomorph records from Tso Moriri (Trans-Himalaya, NW India) for reconstructing Holocene limnology and humanenvironmental interactions, Quat. Int., 348, 113-129, https://doi.org/10.1016/j.quaint.2014.02.026, 2014.

Leipe, C., Müller, S., Hille, K., Kato, H., Kobe, F., Schmidt, M., Seyffert, K., Spengler, R., Wagner, M., Weber, A. W., and Tarasov, P. E.: Vegetation change and human impacts on Rebun Island (Northwest Pacific) over the last 6000 years, Quat. Sci. Rev., 193, 129-144, https://doi.org/10.1016/j.quascirev.2018.06.011, 2018.

Leroy, S. A. G.: Paléoclimats plio-pléistocènes en Catalogne et Languedoc d'après la palynologie de formations lacustres, $\mathrm{PhD}$ thesis, Catholic University of Leuven, Belgium, 1990. 
Leroy, S. A. G., Lahijani, H. A. K., Djamali, M., Naqinezhad, A., Moghadam, M. V., Arpe, K., Shah-Hosseini, M., Hosseindoust, M., Miller, C. S., Tavakoli, V., Habibi, P., and Naderi Beni, M.: Late Little Ice Age palaeoenvironmental records from the Anzali and Amirkola Lagoons (south Caspian Sea): Vegetation and sea level changes, Palaeogeogr. Palaeoclimatol. Palaeoecol., 302, 415-434, https://doi.org/10.1016/j.palaeo.2011.02.002, 2011.

Leroy, S. A. G., Chalié, F., Wesselingh, F. P., Sanjani, M. S., Lahijani, H. A. K., Athersuch, J., Struck, U., Plunkett, G., Reimer, P. J., Habibi, P., Kabiri, K., Haghani, S., Naderi Beni, A., and Arpe, K.: Multi-proxy indicators in a Pontocaspian system: a depth transect of surface sediment in the SE Caspian Sea, Geol. Belgica, 21, 143-165, https://doi.org/10.20341/gb.2018.008, 2018.

Lopatina, D. A. and Zanina, O. G.: Subrecent spore-pollen spectra from the Lower Kolyma River basin and their importance for the reconstruction of the Quaternary paleogeography of the region, Stratigr. Geol. Correl., 24, 203-211, https://doi.org/10.1134/S0869593816020039, 2016.

Lychagina, E., Zaretskaya, N. E., Chernov, A. V., and Lapteva, E. G.: Interdisciplinary studies of the Cis-Ural Neolithic (Upper Kama basin, Lake Chashkinskoe): Palaeoecological aspects, Doc. Praehist., 40, 208-218, https://doi.org/10.4312/dp.40.16, 2013.

Marinova, E., Harrison, S. P., Bragg, F., Connor, S., de Laet, V., Leroy, S. A. G., Mudie, P., Atanassova, J., Bozilova, E., Caner, H., Cordova, C., Djamali, M., Filipova-Marinova, M., Gerasimenko, N., Jahns, S., Kouli, K., Kotthoff, U., Kvavadze, E., Lazarova, M., Novenko, E., Ramezani, E., Röpke, A., Shumilovskikh, L., Tanţau, I., and Tonkov, S.: Pollen-derived biomes in the Eastern Mediterranean-Black Sea-Caspian-Corridor, J. Biogeogr., 45, 484-499, https://doi.org/10.1111/jbi.13128, 2018.

Makovsky, V. I. and Panova, N. K.: Physico-chemical and palynological data on the peat deposits of the marsh cedar forests of the Prichusovsky part of the Middle Urals, Inf. Mater. Middle Ural Mt. For. Stn. 1976, Sverdl., 5-10, 1978.

Margaritelli, G., Vallefuoco, M., Di Rita, F., Capotondi, L., Bellucci, L. G., Insinga, D. D., Petrosino, P., Bonomo, S., Cacho, I., Cascella, A., Ferraro, L., Florindo, F., Lubritto, C., Lurcock, P. C., Magri, D., Pelosi, N., Rettori, R., and Lirer, F.: Marine response to climate changes during the last five millennia in the central Mediterranean Sea, Glob. Planet. Change, 142, 53-72, https://doi.org/10.1016/j.gloplacha.2016.04.007, 2016.

Matishov, G. G., Novenko, E. Y., and Krasnorutskaya, K. V: Landscapes of the Azov Sea in the Late Holocene, Bull. South. Sci. Cent. RAS, 7, 35-43, 2011.

Matthias, I., Nielsen, A. B., and Giesecke, T.: Evaluating the effect of flowering age and forest structure on pollen productivity estimates, Veg. Hist. Archaeobot., 21, 471-484, https://doi.org/10.1007/s00334-012-0373-z, 2012.

Matthias, I., Semmler, M. S. S., and Giesecke, T.: Pollen diversity captures landscape structure and diversity, J. Ecol., 103, 880890, https://doi.org/10.1111/1365-2745.12404, 2015.

Matveev, A. V, Zakh, A. V, Larin, S. I., Dryabina, L. A., and Matveeva, N. P.: Prehistoric cultures and paleogeography of the Mergen archaeological region, in Archeological microdistricts of Western Siberia, Omsk State University, 76-114, 1997.

Matveeva, N. P., Volkov, E. N., and Ryabogina, N.: Antiquities of the Ingal Valley, Archeological microdistricts of Western Siberia, pp. 76-114, 2003.
Mehl, I. K. and Hjelle, K. L.: From deciduous forest to open landscape: application of new approaches to help understand cultural landscape development in western Norway, Veg. Hist. Archaeobot., 25, 153-176, https://doi.org/10.1007/s00334-0150539-6, 2016.

Mercuri, A. M., Bandini Mazzanti, M., Torri, P., Vigliotti, L., Bosi, G., Florenzano, A., Olmi, L., and Massamba N'siala, I.: A marine/terrestrial integration for mid-late Holocene vegetation history and the development of the cultural landscape in the Po Valley as a result of human impact and climate change, Veg. Hist. Archaeobot., 21, 353-372, https://doi.org/10.1007/s00334-012 0352-4, 2012.

Mesa-Fernández, J. M., Jiménez-Moreno, G., Rodrigo-Gámiz, M., García-Alix, A., Jiménez-Espejo, F. J., Martínez-Ruiz, F., Anderson, R. S., Camuera, J., and Ramos-Román, M. J.: Vegetation and geochemical responses to Holocene rapid climate change in the Sierra Nevada (southeastern Iberia): the Laguna Hondera record, Clim. Past, 14, 1687-1706, https://doi.org/10.5194/cp-14-16872018, 2018.

Mikishin, Y. A. and Gvozdeva, I. G.: Subfossil sporo-pollen complexes of Sakhalin Island and adjacent areas, Far Eastern NationalUniversity, https://doi.org/10.17513/np.379, 2009.

Mikishin, Y. A. and Gvozdeva, I. G.: Paleogeography of coast of the Olga bay, Actual Probl. Humanit. Nat. Sci., 10, 325-334, 2012.

Milecka, K., Kowalewski, G., Fiałkiewicz-Kozieł, B., Gałka, M., Lamentowicz, M., Chojnicki, B. H., Goslar, T., and Barabach, J.: Hydrological changes in the Rzecin peatland (Puszcza Notecka, Poland) induced by anthropogenic factors: Implications for mire development and carbon sequestration, The Holocene, 27, 651664, https://doi.org/10.1177/0959683616670468, 2017.

Montali, E., Accorsi, C.A., Trevisan Grandi, G., Mercuri, A.M., Garofano, G., Cervi, A., and Pagani, A.: La "simulazione" come strumento per l'interpretazione in Palinologia forense, GEA, 1, 130-131, 2006.

Montanari, C. and Guido, M. A.: Complessi pollinici rilevati al suolo in centri urbani della Val d Ayas (Aosta), Rev. Vald. d'histoire Nat., 48, 63-86, 1994.

Morales-Molino, C. and García-Antón, M.: Vegetation and fire history since the last glacial maximum in an inland area of the western Mediterranean Basin (Northern Iberian Plateau, NW Spain), Quat. Res., 81, 63-77, https://doi.org/10.1016/j.yqres.2013.10.010, 2014.

Morales-Molino, C., García Antón, M., and Morla, C.: Late Holocene vegetation dynamics on an AtlanticMediterranean mountain in NW Iberia, Palaeogeogr. Palaeoclimatol. Palaeoecol., 302, 323-337, https://doi.org/10.1016/j.palaeo.2011.01.020, 2011.

Morales-Molino, C., García-Antón, M., Postigo-Mijarra, J. M., and Morla, C.: Holocene vegetation, fire and climate interactions on the westernmost fringe of the Mediterranean Basin, Quat. Sci. Rev., 59, 5-17, https://doi.org/10.1016/j.quascirev.2012.10.027, 2013.

Morales-Molino, C., Colombaroli, D., Valbuena-Carabaña, M., Tinner, W., Salomón, R. L., Carrión, J. S., and Gil, L.: Land-use history as a major driver for long-term forest dynamics in the Sierra de Guadarrama National Park (central Spain) during the last millennia: implications for forest conservation and management, Glob. Planet. Change, 152, 64-75, https://doi.org/10.1016/j.gloplacha.2017.02.012, 2017a. 
Morales-Molino, C., Tinner, W., García-Antón, M., and Colombaroli, D.: The historical demise of Pinus nigra forests in the Northern Iberian Plateau (south-western Europe), J. Ecol., 105, 634-646, https://doi.org/10.1111/1365-2745.12702, 2017b.

Morales-Molino, C., Colombaroli, D., Tinner, W., Perea, R., Valbuena-Carabaña, M., Carrión, J. S., and Gil, L.: Vegetation and fire dynamics during the last 4000 years in the Cabañeros National Park (central Spain), Rev. Palaeobot. Palynol., 253, 110122, https://doi.org/10.1016/j.revpalbo.2018.04.001, 2018.

Mrotzek, A., Couwenberg, J., Theuerkauf, M. and Joosten, H.: MARCO POLO - A new and simple tool for pollen-based standscale vegetation reconstruction, The Holocene, 27, 321-330, https://doi.org/10.1177/0959683616660171, 2017.

Müller, S., Tarasov, P. E., Andreev, A. A., Tütken, T., Gartz, S., and Diekmann, B.: Late Quaternary vegetation and environments in the Verkhoyansk Mountains region (NE Asia) reconstructed from a 50-kyr fossil pollen record from Lake Billyakh, Quat. Sci. Rev., 29, 2071-2086, https://doi.org/10.1016/j.quascirev.2010.04.024, 2010.

Muñoz Sobrino, C., García-Moreiras, I., Castro, Y., Martínez Carreño, N., de Blas, E., Fernández Rodríguez, C., Judd, A., and García-Gil, S.: Climate and anthropogenic factors influencing an estuarine ecosystem from NW Iberia: new high resolution multiproxy analyses from San Simón Bay (Ría de Vigo), Quat. Sci. Rev., 93, 11-33, https://doi.org/10.1016/j.quascirev.2014.03.021, 2014.

Naidina, O. D. and Richards, K.: The Akchagylian stage (late Pliocene-early Pleistocene) in the North Caspian region: Pollen evidence for vegetation and climate change in the Urals-Emba region, Quat. Int., 540, 22-37, https://doi.org/10.1016/j.quaint.2018.12.012, 2018.

Nepomilueva, N. I. and Duryagin, D. A.: On the history of the larch forests of the middle Timman in the Holocene (Komi ASSR), Bot. J., 3, 326-335, 1990.

Ni, J., Chen, Y., Herzschuh, U., and Dong, D.: Late Quaternary pollen records in China, Chinese Journal of Plant Ecology, 34, 1000-1005, https://doi.org/10.3773/j.issn.1005264x.2010.08.013, 2010.

Niemeyer, B., Epp, L. S., Stoof-Leichsenring, K. R., Pestryakova, L. A., and Herzschuh, U.: A comparison of sedimentary DNA and pollen from lake sediments in recording vegetation composition at the Siberian treeline, Mol. Ecol. Resour., 17, e46-e62, https://doi.org/10.1111/1755-0998.12689, 2017.

Nikiforova, L. D.: Subcentrous spore-pollen spectra of the middle taiga of the northeast of the European part of the USSR, Bot. J., 63, 868-885, 1978.

Ning, W., Nielsen, A. B., Ivarsson, L. N., Jilbert, T., Åkesson, C., Slomp, C. P., Andrén, E., Broström, A., and Filipsson, H. L.: Anthropogenic and climatic impacts on a coastal environment in the Baltic Sea over the last 1000 years, Anthropocene, 21, 66-79, https://doi.org/10.1016/j.ancene.2018.02.003, 2018.

Novenko, E. Y., Nosova, M. B. and Krasnorutskaya, K. V: Specific features of surface spore-pollen spectra in the southern taiga subzone of the East European Plain, Izv. Tul'sk. Gos. Univ., Ser. Estestv. Nauk., 2, 345-354, 2011.

Novenko, E. Y., Rudenko, O. V, Volkova, E. M. and Zyganova, I. S.: Dinamika rastitel'nosti natsional'nogo parka Orlovskoye polesye $\mathrm{v}$ pozdnem golotsene $=$ Vegetation dynamics in the Orlovskoye Polesye National Park in Late Holocene (in Russian), Uchenye
Zap. Orlov. Gos. Univ. Seriya Estestv. Tekhnicheskie i Meditsinskie Nauk. Sci. Notes Orel State Univ. Nat. Tech. Med. Sci. Ser., 3, 302-310, 2014.

Novenko, E. Y., Mazei, N. G., and Zernitskaya, V. P.: Recent pollen assemblages from Protected Areas of European Russia as a key to interpreting the results of paleoecological studies, Nat. Conserv. Res., 2, https://doi.org/10.24189/ncr.2017.012, 2017.

Olson, D. M., Dinerstein, E., Wikramanayake, E. D., Burgess, N. D., Powell, G. V. N., Underwood, E. C., D'amico, J. A., Itoua, I., Strand, H. E., Morrison, J. C., Loucks, C. J., Allnutt, T. F., Ricketts, T. H., Kura, Y., Lamoreux, J. F., Wettengel, W. W., Hedao, P., and Kassem, K. R.: Terrestrial Ecoregions of the World: A New Map of Life on Earth, Bioscience, 51, 933-938, https://doi.org/10.1641/00063568(2001)051[0933:teotwa]2.0.co;2, 2001.

Panova, N. K.: Formation of the plant cover of the middle mountain high-altitude belt of the Southern Urals with climate changes in the Holocene, Interrelat. Environ. For. Veg. Ural. Sverdl., 40-57, 1981.

Panova, N. K., Makovsky, V. I., and Erokhin, N. G.: Holocene vegetation dynamics in the area of the Krasnoufim forest-steppe, For. Form. Process Ural. Transurals. Ekaterinburg, Ural Branch RAS., 80-93, 1996.

Panova, N. K., Antipina, T. G., and Jankovska, V.: Holocene history of the environment and development of bogs on the eastern slope of the Polar and Pre-Polar Urals, Environ. Dyn. Glob. Clim. Chang., 1, 8, 2010.

Panova, N. T. and Korotkovskaya, T. G.: Palynological study of the peat bog near lake. Sandy, For. Palynol. Stud. swamps Middle Ural. Sverdl., 47-55, 1990.

Panova, N. T. and Makowski, V. I.: the history of the mountain forests of the Visimskiy reserve in the Holocene, Proc. plant Anim. Ecol. UC USSR Acad. Sci., 128, 25-33, 1979.

Panova, N. T., Trofimova, S. S., and Erokhin, N. D.: On the history of vegetation and climatic conditions in the southern Yamal in the Holocene, Fauna flora North, Eurasia late Cenozoic, Sat. Sci. Pap. Ekaterinburg-Chelyabinsk, 249-259, 2008.

Pardoe, H. S.: The relationship between modern pollen deposition and vegetation: studies from alpine and sub-alpine communities on glacier forelands in southern Norway, $\mathrm{PhD}$ thesis, University of Wales, UK, 1992.

Pardoe, H. S.: The representation of taxa in surface pollen spectra on alpine and sub-alpine glacier forelands in southern Norway, Rev. Palaeobot. Palynol., 117, 63-78, https://doi.org/10.1016/S00346667(01)00077-X, 2001.

Pardoe, H. S.: Surface pollen deposition on glacier forelands in southern Norway I: local patterns of representation and source area at Storbreen, Jotunheimen, The Holocene, 16, 1149-1161, https://doi.org/10.1177/0959683606069422, 2006.

Pardoe, H. S.: Surface pollen deposition on glacier forelands in southern Norway II: Spatial patterns across the Jotunheimen-Jostedalsbreen region, The Holocene, 24, 16751685, https://doi.org/10.1177/0959683614551213, 2014.

Pardoe, H. S., Giesecke, T., van der Knaap, W. O., SvitavskáSvobodová, H., Kvavadze, E. V., Panajiotidis, S., Gerasimidis, A., Pidek, I. A., Zimny, M., Święta-Musznicka, J., Latałowa, M., Noryśkiewicz, A. M., Bozilova, E., Tonkov, S., FilipovaMarinova, M. V., van Leeuwen, J. F. N., and Kalniòa, L.: Comparing pollen spectra from modified Tauber traps 
and moss samples: examples from a selection of woodlands across Europe, Veg. Hist. Archaeobot., 19, 271-283, https://doi.org/10.1007/s00334-010-0258-y, 2010.

Pędziszewska, A.: Late Holocene history of forest stands with hornbeam (Carpinus betulus L.) and beech (Fagus sylvatica L.) in the Kashubian Lakeland, PhD thesis, University of Gdańsk, 2008.

Pędziszewska, A. and Latałowa, M.: Stand-scale reconstruction of late Holocene forest succession on the Gdańsk Upland (N. Poland) based on integrated palynological and macrofossil data from paired sites, Veg. Hist. Archaeobot., 25, 239-254, https://doi.org/10.1007/s00334-015-0546-7, 2016.

Pędziszewska, A., Tylmann, W., Witak, M., Piotrowska, N., Maciejewska, E., and Latałowa, M.: Holocene environmental changes reflected by pollen, diatoms, and geochemistry of annually laminated sediments of Lake Suminko in the Kashubian Lake District (N Poland), Rev. Palaeobot. Palynol., 216, 55-75, https://doi.org/10.1016/j.revpalbo.2015.01.008, 2015.

Petrenko, T. I., Mikishin, Y. A., and Belyanina, N. I.: Subfossil spore-pollen complexes of the Khanka Lake Plain in the Primorye Region, Russia, Nat. Tech. Sci., 4, 162-171, 2009.

Pidek, I. A., Svitavská-Svobodová, H., van der Knaap, W. O., Noryśkiewicz, A. M., Filbrandt-Czaja, A., Noryśkiewicz, B., Latałowa, M., Zimny, M., Święta-Musznicka, J., Bozilova, E., Tonkov, S., Filipova-Marinova, M. V., Poska, A., Giesecke, T., and Gikov, A.: Variation in annual pollen accumulation rates of Fagus along a N-S transect in Europe based on pollen traps, Veg. Hist. Archaeobot., 19, 259-270, https://doi.org/10.1007/s00334010-0248-0, 2010.

Poshekhonova, O. E., Semenova, V. I., Ivanov, S. N., Ryabogina, N., and Yakimov, A. S.: Archaeological and paleoecological studies of the medieval settlement Vyngayakha 7 (north taiga part of the Pur river basin), Bull. Archaeol. Anthropol. Ethnogr., 9, 181195, 2008.

Prentice, I. C. and Webb, T.: BIOME 6000: Reconstructing global mid-Holocene vegetation patterns from palaeoecological records, J. Biogeogr., 25, 997-1005, https://doi.org/10.1046/j.1365-2699.1998.00235.x, 1998.

Ramezani, E., Marvie Mohadjer, M. R., Knapp, H.-D., Theuerkauf, M., Manthey, M., and Joosten, H.: Pollen-vegetation relationships in the central Caspian (Hyrcanian) forests of northern Iran, Rev. Palaeobot. Palynol., 189, 38-49, https://doi.org/10.1016/j.revpalbo.2012.10.004, 2013.

Ramos-Román, M. J., Jiménez-Moreno, G., Anderson, R. S., García-Alix, A., Toney, J. L., Jiménez-Espejo, F. J., and Carrión, J. S.: Centennial-scale vegetation and North Atlantic Oscillation changes during the Late Holocene in the southern Iberia, Quat. Sci. Rev., 143, 84-95, https://doi.org/10.1016/j.quascirev.2016.05.007, 2016.

Ramos-Román, M. J., Jiménez-Moreno, G., Camuera, J., GarcíaAlix, A., Anderson, R. S., Jiménez-Espejo, F. J., and Carrión, J. S.: Holocene climate aridification trend and human impact interrupted by millennial- and centennial-scale climate fluctuations from a new sedimentary record from Padul (Sierra Nevada, southern Iberian Peninsula), Clim. Past, 14, 117-137, https://doi.org/10.5194/cp-14-117-2018, 2018.

Rattighieri, E., Florenzano, A., Mercuri, A. M., and Levi, S. T.: Una ricostruzione archeoambientale del sito di San Vincenzo, villaggio del bronzo a Stromboli, Atti della Soc. dei Nat. e Mat. di Modena, 141, 219-230, 2010.
Rattighieri, E., Florenzano, A., Mercuri, A. M., and Levi, S.: Palinologia applicata al sito di San Vincenzo-Stromboli (Bronzo Medio) per una ricostruzione archeoambientale, VII Congresso Nazionale di Archeometria, 442-450, 2012.

Rösch, M.: Zur vorgeschichtlichen Besiedlung und Landnutzung im nørdlichen Schwarzwald aufgrund vegetationsgeschichtlicher Untersuchungen in zwei Karseen, Mitt. Ver. Forstl. Standortskd. Forstpflanzenz., 46, 69-82, 2009.

Rösch, M.: Vegetation und Waldnutzung im Nordschwarzwald während sechs Jahrtausenden anhand von Profundalkernen aus dem Herrenwieser See, Mitt. Ver. für Forstl. Standortskd. Forstpflanzenz., 47, 43-64, 2012.

Rösch, M.: Change of land use during the last two millennia as indicated in the pollen record of a profundal core from Mindelsee, Lake Constance region, southwest Germany, Offa, 69, 355-370, 2013.

Rösch, M.: Evidence for rare crop weeds of the Caucalidion group in Southwestern Germany since the Bronze Age: palaeoecological implications, Veg. Hist. Archaeobot., 27, 7584, https://doi.org/10.1007/s00334-017-0615-1, 2018.

Rösch, M. and Lechterbeck, J.: Seven Millennia of human impact as reflected in a high resolution pollen profile from the profundal sediments of Litzelsee, Lake Constance region, Germany, Veg. Hist. Archaeobot., 25, 339-358, https://doi.org/10.1007/s00334015-0552-9, 2016.

Rösch, M. and Tserendorj, G.: Der Nordschwarzwald - früher besiedelt als gedacht? Pollenprofile belegen ausgedehnte vorgeschichtliche Besiedlung und Landnutzung, Denkmalpflege in Baden-Württemberg, 40, 66-73, 2011a.

Rösch, M. and Tserendorj, G.: Florengeschichtliche Beobachtungen im Nordschwarzwald (Südwestdeutschland), Hercynia-Økologie und Umwelt Mitteleuropa, 44, 53-71, 2011b.

Rösch, M. and Wick, L.: Buchensee (Lake Constance region, Germany), Grana, 58, 308-310, https://doi.org/10.1080/00173134.2019.1569127, 2019.

Rösch, M., Fischer, E., and Lechterbeck, J.: Kontrapunkte?: Festschrift für Manfred Rösch, Verlag Dr. Rudolf Habelt GmbH, Bonn, 2017.

Ryabogina, N. and Orlova, L. A.: Late Holocene peat bog Gladilovsky Ryam as an indicator of changes in the paleoecological conditions of the Ishim plain, Bull. Archaeol. Anthropol. Ethnogr., 4, 203-214, 2002.

Salonen, J. S., Seppä, H., Väliranta, M., Jones, V. J., Self, A., Heikkilä, M., Kultti, S., and Yang, H.: The Holocene thermal maximum and late-Holocene cooling in the tundra of NE European Russia, Quat. Res., 75, 501-511, https://doi.org/10.1016/j.yqres.2011.01.007, 2011.

Salonen, J. S., Ilvonen, L., Seppä, H., Holmström, L., Telford, R. J., Gaidamavičius, A., Stančikaite, M., and Subetto, D.: Comparing different calibration methods (WA/WA-PLS regression and Bayesian modelling) and different-sized calibration sets in pollen-based quantitative climate reconstruction, The Holocene, 22, 413-424, https://doi.org/10.1177/0959683611425548, 2012.

Sapelko, T. and Nosevich, E.: Holocene palaeoenvironmental changes on the North Kola Peninsula: formation of modern landscapes, Abstracts of Past Gateways, First International conference and workshop, St. Petersburg, 1317 May 2013, available at: http://www.geol.lu.se/pastgateways/ 
docs/PastGate-ways2013-abstracts.pdf (last access: 2 February 2016), 2013.

Schofield, J. E., Edwards, K. J., and McMullen, A. J.: Modern pollen-vegetation relationships in subarctic southern Greenland and the interpretation of fossil pollen data from the Norse landnám, J. Biogeogr., 34, 473-488, https://doi.org/10.1111/j.13652699.2006.01607.x, 2007.

Shavnin, S. A., Yusupov, I. A., Artemyeva, E. P., and Golikov, D. Y.: The effect of increasing temperature on the formation of terrestrial vegetation near a gas torch, For. J., 1, 21-28, 2006.

Sommer, P. S., Chevalier, M., and Davis, B. A. S.: EMPD2/EMPDdata: Eurasian Modern Pollen Database (EMPD), Version 2 (Version v2.0), Zenodo, https://doi.org/10.5281/zenodo.4066498, 2020.

Stivrins, N., Kalniòa, L., Veski, S., and Zeimule, S.: Local and regional Holocene vegetation dynamics at two sites in eastern Latvia, Boreal Environ. Res., 19, 310-322, 2014.

Stivrins, N., Brown, A., Reitalu, T., Veski, S., Heinsalu, A., Banerjea, R. Y., and Elmi, K.: Landscape change in central Latvia since the Iron Age: multi-proxy analysis of the vegetation impact of conflict, colonization and economic expansion during the last 2,000 years, Veg. Hist. Archaeobot., 24, 377-391, https://doi.org/10.1007/s00334-014-0502-y, 2015a.

Stivrins, N., Kołaczek, P., Reitalu, T., Seppä, H., and Veski, S.: Phytoplankton response to the environmental and climatic variability in a temperate lake over the last 14,500 years in eastern Latvia, J. Paleolimnol., 54, 103-119, https://doi.org/10.1007/s10933-0159840-8, 2015b.

Stivrins, N., Wulf, S., Wastegård, S., Lind, E. M., Alliksaar, T., Gałka, M., Andersen, T. J., Heinsalu, A., Seppä, H., and Veski, S.: Detection of the Askja AD 1875 cryptotephra in Latvia, Eastern Europe, J. Quat. Sci., 31, 437-441, https://doi.org/10.1002/jqs.2868, 2016a.

Stivrins, N., Brown, A., Veski, S., Ratniece, V., Heinsalu, A., Austin, J., Liiv, M., and Ceriòa, A.: Palaeoenvironmental evidence for the impact of the crusades on the local and regional environment of medieval (13th-16th century) northern Latvia, eastern Baltic, The Holocene, 26, 61-69, https://doi.org/10.1177/0959683615596821, 2016b.

Stivrins, N., Liiv, M., Heinsalu, A., Gałka, M., and Veski, S.: The final meltdown of dead-ice at the Holocene Thermal Maximum (8500-7400 cal. yr BP) in western Latvia, eastern Baltic, The Holocene, 27, 1146-1157, https://doi.org/10.1177/0959683616683255, 2017a.

Stivrins, N., Buchan, M. S., Disbrey, H. R., Kuosmanen, N., Latałowa, M., Lempinen, J., Muukkonen, P., Słowiński, M., Veski, S., and Seppä, H.: Widespread, episodic decline of alder (Alnus) during the medieval period in the boreal forest of Europe, J. Quat. Sci., 32, 903-907, https://doi.org/10.1002/jqs.2984, $2017 b$.

Stojakowits, P.: Pollenanalytische Untersuchungen zur Rekonstruktion der Vegetationsgeschichte im sädlichen Iller-WertachJungmoränengebiet seit dem Spätglazial, 2015.

Surova, T. G. and Troitsky, L. S.: On the dynamics of vegetation cover, climate and glaciations in the Polar Urals Holocene (by the data of pollen analyses), Paliniloghiya golocena, 121-135, 1971.
Svobodová, H.: A reconstruction of natural environment and settlement in the environs of Mistrin (A palynological study, Czeck), Pamatky Archeol., 80, 188-206, 1989.

Svobodová, H.: Die Entwicklung der Vegetation in Sädmähren (Tschechien) während des Spätglazials und Holozäns-eine palynologische Studie, Verhandlungen der Zool. Gesellschaft Østerreich, 134, 317-356, 1997.

Svobodová, H.: Preliminary results of the vegetation history in the giant mountains (Úpská raselina mire and Cernohorská raselina bog)/Predbezné vysledky k historii vegetace Krkonos (Úpská raselina a Cernohorská raselina), Opera Corcon., 5, 5-15, 2002.

Svobodová, H., Reille, M., and Goeury, C.: Past vegetation dynamics of Vltavský luh, upper Vltava river valley in the Šumava mountains. Czech Republic, Veg. Hist. Archaeobot., 10, 185199, https://doi.org/10.1007/PL00006930, 2001.

Tanţău, I., Reille, M., de Beaulieu, J.-L., Farcas, S., and Brewer, S.: Holocene vegetation history in Romanian Subcarpathians, Quat. Res., 72, 164-173, https://doi.org/10.1016/j.yqres.2009.05.002, 2009.

Tanţău, I., Feurdean, A. N., de Beaulieu, J.-L., Reille, M., and Fărcaş, S.: Holocene vegetation history in the upper forest belt of the Eastern Romanian Carpathians, Palaeogeogr. Palaeoclimatol. Palaeoecol., 309, 281-290, https://doi.org/10.1016/j.palaeo.2011.06.011, 2011.

Tanţău, I., Geanta, A., Feurdean, A. N., and Tămaş, T.: Pollen analysis from a high altitude site in Rodna Mountains (Romania), Carpathian J. Earth Environ. Sci., 9, 23-30, 2014a.

Tanţău, I., Feurdean, A. N., de Beaulieu, J.-L., Reille, M., and FĂRCAŞ, S.: Vegetation sensitivity to climate changes and human impact in the Harghita Mountains (Eastern Romanian Carpathians) over the past 15000 years, J. Quat. Sci., 29, 141-152, https://doi.org/10.1002/jqs.2688, 2014b.

Tarasov, P. E., Nakagawa, T., Demske, D., Österle, H., Igarashi, Y., Kitagawa, J., Mokhova, L., Bazarova, V., Okuda, M., Gotanda, K., Miyoshi, N., Fujiki, T., Takemura, K., Yonenobu, H., and Fleck, A.: Progress in the reconstruction of Quaternary climate dynamics in the Northwest Pacific: A new modern analogue reference dataset and its application to the 430-kyr pollen record from Lake Biwa, Earth Sci. Rev., 108, 64-79, https://doi.org/10.1016/j.earscirev.2011.06.002, 2011.

Veski, S., Amon, L., Heinsalu, A., Reitalu, T., Saarse, L., Stivrins, N., and Vassiljev, J.: Lateglacial vegetation dynamics in the eastern Baltic region between 14,500 and 11,400calyrBP: A complete record since the Bølling (GI-1e) to the Holocene, Quat. Sci. Rev., 40, 39-53, https://doi.org/10.1016/j.quascirev.2012.02.013, 2012.

Vincens, A., Leźine, A. M., Buchet, G., Lewden, D., Le Thomas, A., Agwu, C. O. C., Azéma, C., Ballouche, A., Baxter, A., Bengo, M. D., Beuning, K., Bolick, M. R., Bonnefille, R., Bousman, C. B., Buchet, N., Bumey, D. A., Caratini, C., Carrion, J. S., Cazet, J. P., Cohen, J., Cooresman, B., Cour, P., Denèfle, M., Dupont, L., Duzer, D., Edorh, T., El Ghazali, G. E. B., El Moslimany, A. P., El Moutaki, S., Elenga, H., Guinet, P., Hamilton, A. C., Hedberg, O., Hooghiemstra, H., Irving, S. J. E., Jahns, S., Jolly, D., Kadomura, H., Kendall, R. L., Lamb, H. F., Laseski, R. A., Leroy, S., Livingstone, D. A., Magioncalda, R., Maley, J., Marchant, R., Marret, F., Matsumoto, K., Meadows, M., Mercuri, A. M., Mohammed, U. M., Morrison, M. E. S., Moscol-Olivera, M. C., Nakimera-Ssemmanda, I., Nta- 
ganda, C., Nyakale, M., Osadtchy, C., Perrott, R. A., Pons, A., Quézel, P., Reynaud-Farrera, I., Riollet, G., Ritchie, J. C., Roche, E., Rucina, S. M., Salzmann, U., Schulz, E., Scott, L., Shi, N., Soulet, G., Sowunmi, M. A., Straka, H., Sugden, J. M., Taylor, D., Tissot, C., Van Campo, E., Van Campo, M., Van Zinderen Bakker, E. M., Vilimumbalo, S., Waller, M. P., Watrin, J., and Ybert, J. P.: African pollen database inventory of tree and shrub pollen types, Rev. Palaeobot. Palynol., 145, 135-141, https://doi.org/10.1016/j.revpalbo.2006.09.004, 2007.
Zakh, A. V: Mnogosloynoe poselenie Parom 1 u Saleharda [Parom 1 Multi-Layered Settlement near Salekhard], Bull. Archaeol. Anthropol. Ethnogr., 1, 23-35, 1997.

Zheng, Z., Wei, J., Huang, K., Xu, Q., Lu, H., Tarasov, P., Luo, C., Beaudouin, C., Deng, Y., Pan, A., Zheng, Y., Luo, Y., Nakagawa, T., Li, C., Yang, S., Peng, H., and Cheddadi, R.: East Asian pollen database: Modern pollen distribution and its quantitative relationship with vegetation and climate, J. Biogeogr., 41, 18191832, https://doi.org/10.1111/jbi.12361, 2014. 